US Army Corps

of Engineers ${ }_{\circledast}$

Engineer Research and

Development Center

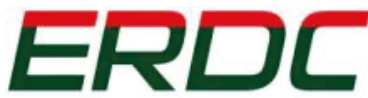

INNOVATIVE SOLUTIONS

for a safer, better world

Integrated Climate Assessment for Army Enterprise Planning

\title{
Use of Heat and Fire-Risk Indices to Project Local Climate Impacts on Selected Army Installations
}

Climate Models, Scenarios, Climate Data, and Indices

John W. Weatherly and Mattson A. Rosenbaum

November 2017

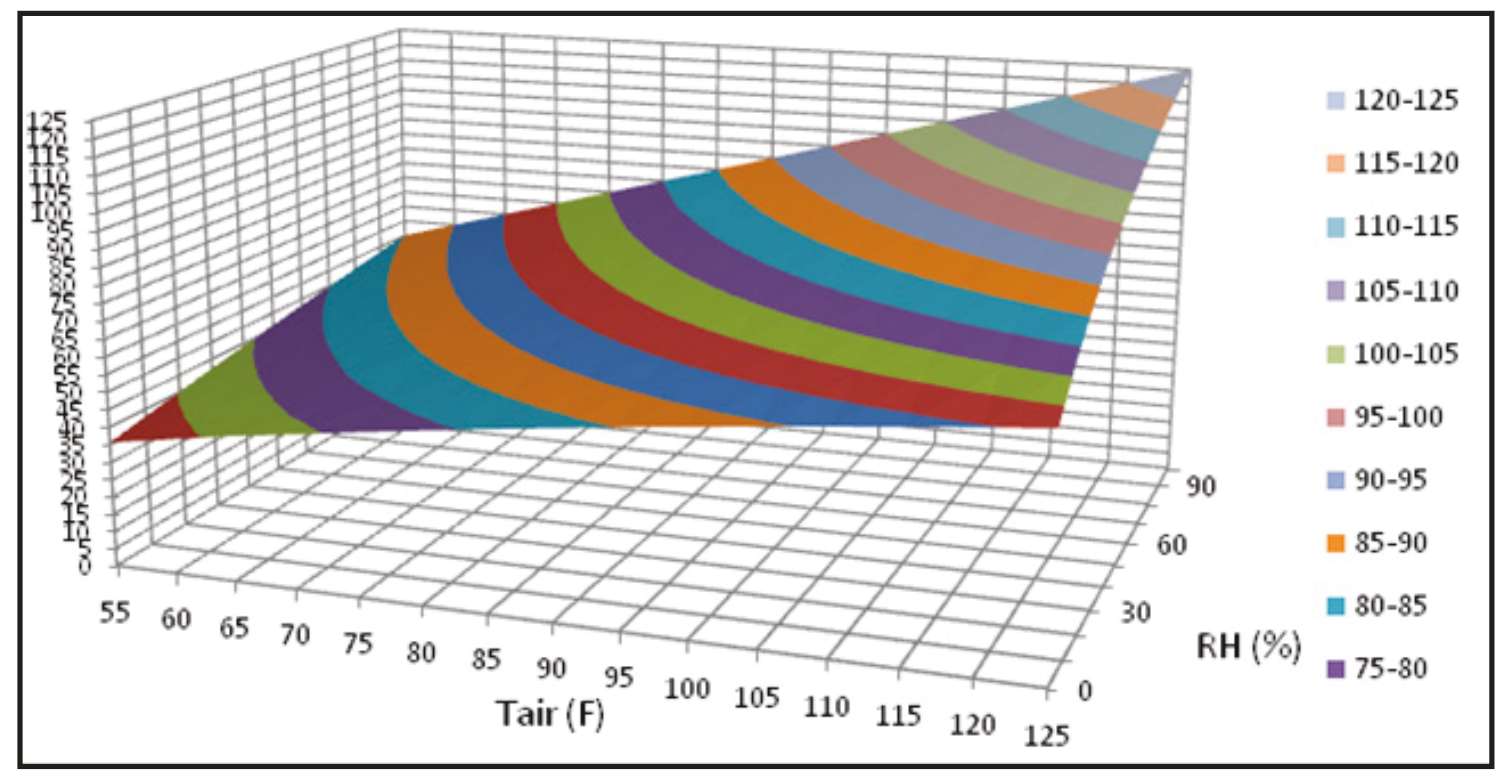

Wet bulb temperature as function of air temperature and relative humidity at mean sea level used in the calculation of WBGT. 
The U.S. Army Engineer Research and Development Center (ERDC) solves the nation's toughest engineering and environmental challenges. ERDC develops innovative solutions in civil and military engineering, geospatial sciences, water resources, and environmental sciences for the Army, the Department of Defense, civilian agencies, and our nation's public good. Find out more at www.erdc.usace.army.mil.

To search for other technical reports published by ERDC, visit the ERDC online library at http://acwc.sdp.sirsi.net/client/default. 


\section{Use of Heat and Fire-Risk Indices to Project Local Climate Impacts on Selected Army Installations}

Climate Models, Scenarios, Climate Data, and Indices

John W. Weatherly and Mattson A. Rosenbaum

U.S. Army Engineer Research and Development Center (ERDC)

Cold Regions Research and Engineering Laboratory (CRREL)

72 Lyme Road

Hanover, NH 03755-1290

Final Report

Approved for public release; distribution is unlimited.

Prepared for Headquarters, U.S. Army Corps of Engineers

Washington, DC 20314-1000

Under Project 622720A896, "Environmental Quality Guidance," Work Package "Integrated Climate Assessment for Army Enterprise Planning," Work Unit L4F5G1 


\section{Abstract}

Climate change is expected to produce increasing impacts on training and infrastructure on Army installations in the coming decades. Planning to enable Army installations to adapt to the changing climate can be supported by suitable estimates of climate impacts over timeframes suitable for strategic plans. This work computed the impacts of future climate change on available training days for seven sample Army installations using projections of temperature and precipitation from global climate models. The number of days with heat-related training restrictions and fire risk from live-fire training were calculated using observed weather station data and climate model projections for several future climate scenarios. For these installations, increased temperatures in time periods centered on 2030, 2050, and 2090 result in a greater number of days with heat categories above 84 and $90{ }^{\circ} \mathrm{F}\left(28.9\right.$ and $\left.32.2^{\circ} \mathrm{C}\right)$ and with high fire risk. The climate impact on heat-affected training days is greater in the U.S. Southeast, where high humidity also contributes most to the heat index. The impact on the fire risk for training is greater in the U.S. Southwest, where the low precipitation and high temperatures contribute to the high drought index. Future work will include additional installations and climate variables.

DISCLAIMER: The contents of this report are not to be used for advertising, publication, or promotional purposes. Citation of trade names does not constitute an official endorsement or approval of the use of such commercial products. All product names and trademarks cited are the property of their respective owners. The findings of this report are not to be construed as an official Department of the Army position unless so designated by other authorized documents. 


\section{Contents}

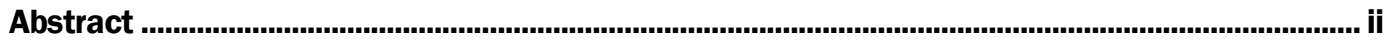

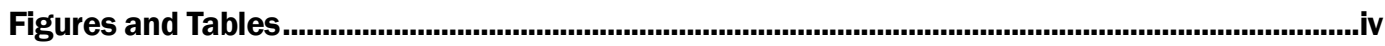

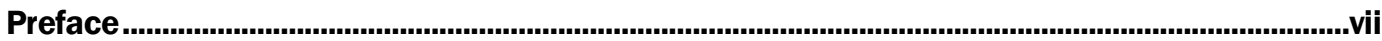

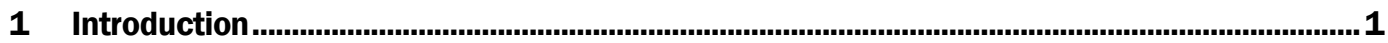

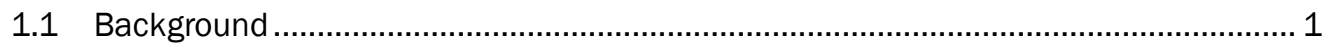

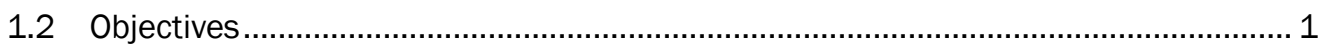

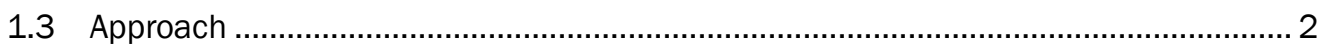

1.4 Mode of technology transfer …….................................................................. 2

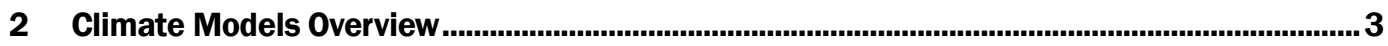

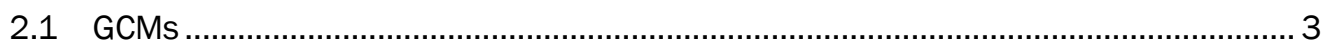

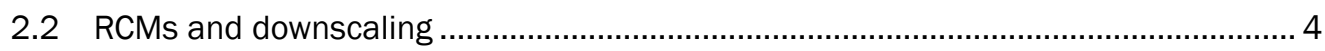

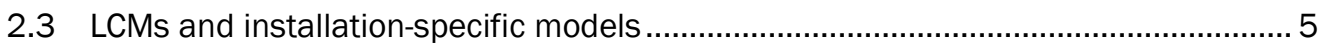

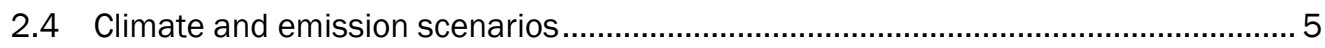

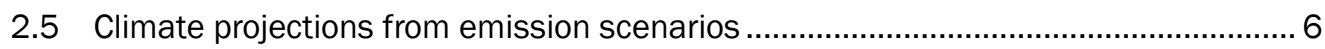

2.6 Uncertainties and agreement in climate projections ............................................... 8

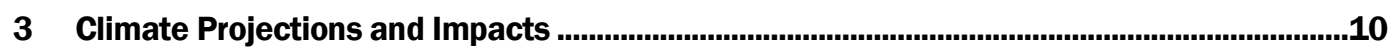

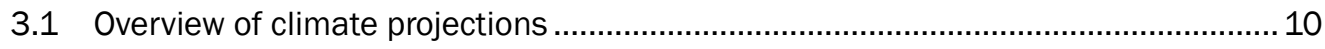

3.2 Downscaled climate projections for regions and installations.................................. 12

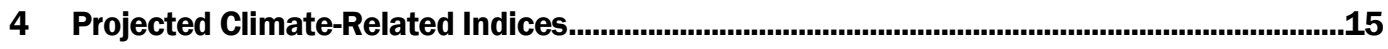

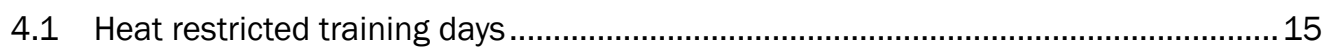

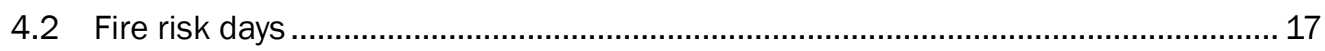

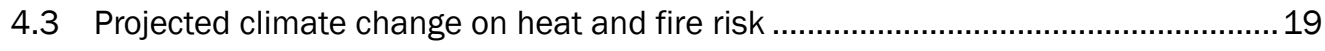

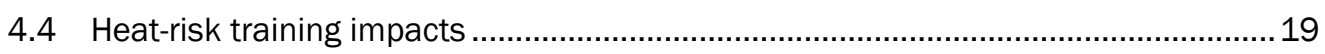

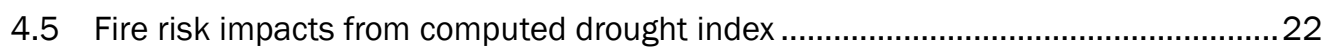

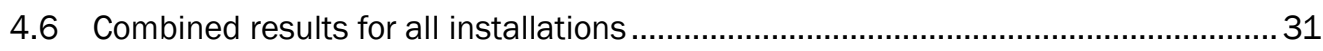

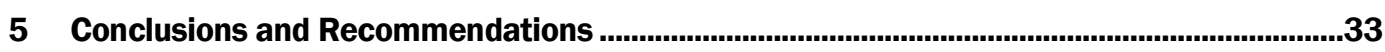

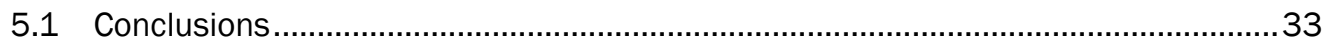

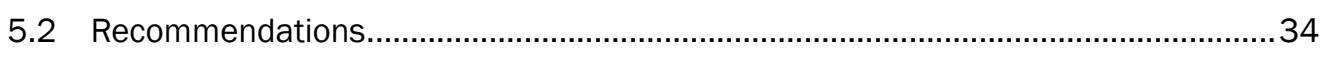

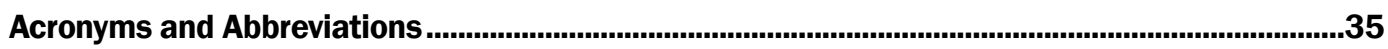

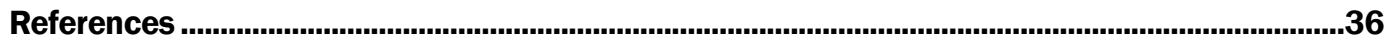

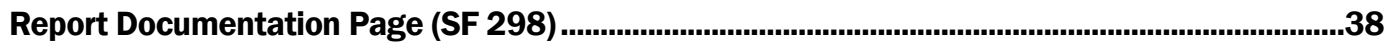




\section{Figures and Tables}

\section{Figures}

2-1 Sequence (top to bottom) of the creation of climate projections. Scenarios of GHG emissions (top) are created by scientific committees based on fossil-fuel use and other trends. GCMs (center) are used to simulate climate change under increasing GHGs, and create global-scale projections (bottom) of temperature change, sea level rise and other variables.

3-1 Upper: Projected change in air temperature $\left({ }^{\circ} \mathrm{F}\right)$ between 1970-1999 and 20712099 for the B1 (lower emission) and the A2 (higher emissions) scenarios. (Lower plot) Projected change in seasonal precipitation (\%) in the A2 scenario, averaged over multiple GCMs.

3-2 Average air temperature $\left({ }^{\circ} \mathrm{F}\right)$ for Fort Bragg, as a 5-year running mean over 1950-2099 for the A2 and B1 scenarios, average over the 36 downscaled GCM simulations. The upper and lower lines show the maximum and minimum annual temperatures of the $36 \mathrm{GCMs}$

3-3 Projected change in air temperature change $\left({ }^{\circ} \mathrm{C}\right)$ versus precipitation change (\%) for Fort Bliss, TX, for each of $36 \mathrm{GCMs}$ from the downscaled CMIP-3 archive for the A2 (high-emission) scenario, between 1980-1999 and 2040-2060 (black points) and 2080-2090 (blue points)

4-1 Graph of wet bulb temperature (Twb, ${ }^{\circ} \mathrm{F}$ ) as function of air temperature (Tair) and relative humidity (\%) at mean sea level used in the calculation of WBGT.

4-2 Average number of days per month with air temperatures $>90^{\circ} \mathrm{F}\left(>32.2^{\circ} \mathrm{C}\right)$ from daily maximum temperatures for Fort Riley KS and Fort Bliss, TX over 19701999

4-3 Monthly average values of the KBDI from daily observations for Fort Riley, KS, Wheeler Air Force Base (AFB), HI, and Fort Bliss, TX over 1979-1999

4-4 Average number of days per year with calculated WBGT in the five heat categories (with temperatures shown) for Fort Bliss, TX. The "Observed Data" column (left) use the daily temperatures, dewpoint, and wind speeds over 19791999, The projected columns (right three) used added temperature changes from climate models centered on years 2030, 2050, and 2080.

4-5 Average number of days per year with calculated KBDI in the categories from Tbl. 4-1 for Fort Bliss, TX. The "Observed Data" column (left) uses the daily recorded temperatures and precipitation over 1979-1999, The projected columns (right three) used added temperature changes from climate models centered on years 2030, 2050, and 2080

4-6 Climate projection plots for Fort Bliss, TX: (a) projected change in air temperature $\left({ }^{\circ} \mathrm{C}\right)$ versus precipitation (\%) for each of $36 \mathrm{GCMs}$ for the $\mathrm{A} 2$ scenario, between 1980-1999 and 2040-2060 (black points) and 2080-2090 (blue points); (b) average number of days per year with calculated WBGT in the five heat categories (with increasing temperatures of 1,2 , and $3{ }^{\circ} \mathrm{C}(3.6,1.8$, and $5.4^{\circ} \mathrm{F}$ ); (c) average number of days per year with calculated $\mathrm{KBDI}$ categories with increasing temperatures of 1,2 , and $3^{\circ} \mathrm{C}\left(3.6,1.8\right.$, and $\left.5.4^{\circ} \mathrm{F}\right)$... 
4-7 Climate projection plots for Fort Bragg, NC: (a) projected change in air temperature $\left({ }^{\circ} \mathrm{C}\right.$ ) versus precipitation (\%) for each of $36 \mathrm{GCMs}$ for the A2 scenario, between 1980-1999 and 2040-2060 (black points) and 2080-2090 (blue points); (b) average number of days per year with calculated WBGT in the five heat categories (with increasing temperatures of 1,2 , and $3{ }^{\circ} \mathrm{C}(3.6,1.8$, and $\left.5.4^{\circ} \mathrm{F}\right) ;(\mathrm{c})$ average number of days per year with calculated $\mathrm{KBDI}$ categories with increasing temperatures of 1,2 , and $3^{\circ} \mathrm{C}\left(3.6,1.8\right.$, and $\left.5.4{ }^{\circ} \mathrm{F}\right)$

4-8 Climate projection plots for Fort Drum, NY: (a) projected change in air temperature $\left({ }^{\circ} \mathrm{C}\right.$ ) versus precipitation (\%) for each of $36 \mathrm{GCMs}$ for the A2 scenario, between 1980-1999 and 2040-2060 (black points) and 2080-2090 (blue points); (b) average number of days per year with calculated WBGT in the five heat categories (with increasing temperatures of 1,2 , and $3{ }^{\circ} \mathrm{C}(3.6,1.8$, and $\left.5.4^{\circ} \mathrm{F}\right)$; (c) average number of days per year with calculated KBDI categories with increasing temperatures of 1,2 , and $3^{\circ} \mathrm{C}\left(3.6,1.8\right.$, and $\left.5.4^{\circ} \mathrm{F}\right)$

4-9 Climate projection plots for Joint Base Lewis-McChord, WA: (a) projected change in air temperature $\left({ }^{\circ} \mathrm{C}\right.$ ) versus precipitation (\%) for each of $36 \mathrm{GCMs}$ for the A2 scenario, between 1980-1999 and 2040-2060 (black points) and 2080-2090 (blue points); (b) average number of days per year with calculated WBGT in the five heat categories (with increasing temperatures of 1,2 , and $3{ }^{\circ} \mathrm{C}(3.6,1.8$, and $\left.5.4^{\circ} \mathrm{F}\right)$; (c) average number of days per year with calculated KBDI categories with increasing temperatures of 1,2 , and $3^{\circ} \mathrm{C}\left(3.6,1.8\right.$, and $\left.5.4^{\circ} \mathrm{F}\right)$

4-10 Climate projection plots for Fort Riley, KS: (a) projected change in air temperature $\left({ }^{\circ} \mathrm{C}\right.$ ) versus precipitation (\%) for each of $36 \mathrm{GCMs}$ for the A2 scenario, between 1980-1999 and 2040-2060 (black points) and 2080-2090 (blue points); (b) average number of days per year with calculated WBGT in the five heat categories (with increasing temperatures of 1,2 , and $3{ }^{\circ} \mathrm{C}(3.6,1.8$, and $\left.5.4^{\circ} \mathrm{F}\right)$; (c) average number of days per year with calculated KBDI categories with increasing temperatures of 1,2 , and $3^{\circ} \mathrm{C}\left(3.6,1.8\right.$, and $\left.5.4^{\circ} \mathrm{F}\right)$

4-11 Climate projection plots for Fort Wainwright, AK: (a) projected change in air temperature $\left({ }^{\circ} \mathrm{C}\right.$ ) versus precipitation (\%) for each of $36 \mathrm{GCMs}$ for the $\mathrm{A} 2$ scenario, between 1980-1999 and 2040-2060 (black points) and 2080-2090 (blue points); (b) average number of days per year with calculated WBGT in the five heat categories (with increasing temperatures of 1,2 , and $3{ }^{\circ} \mathrm{C}(3.6,1.8$, and $\left.5.4^{\circ} \mathrm{F}\right) ;(\mathrm{c})$ average number of days per year with calculated KBDI categories with increasing temperatures of 1,2 , and $3^{\circ} \mathrm{C}\left(3.6,1.8\right.$, and $\left.5.4^{\circ} \mathrm{F}\right)$

4-12 Climate projection plots for Wheeler AAF -Schoefield Barracks HI: (a) projected change in air temperature $\left({ }^{\circ} \mathrm{C}\right.$ ) versus precipitation (\%) for each of $36 \mathrm{GCMs}$ for the A2 scenario, between 1980-1999 and 2040-2060 (black points) and 20802090 (blue points); (b) average number of days per year with calculated WBGT in the five heat categories (with increasing temperatures of 1,2 , and $3^{\circ} \mathrm{C}(3.6$, 1.8 , and $\left.5.4^{\circ} \mathrm{F}\right) ;(\mathrm{c})$ average number of days per year with calculated KBDI categories with increasing temperatures of 1,2 , and $3^{\circ} \mathrm{C}\left(3.6,1.8\right.$, and $\left.5.4^{\circ} \mathrm{F}\right)$

\section{Tables}

3-1 Projected changes in air temperature $\left({ }^{\circ} \mathrm{C}\right)$ and precipitation (\%) for 7 example installations, averaged over 36 simulations from the downscaled CMIP-3 archive for the A2 (high-emission) scenario, between 1980-1999 and 2050 and 2080.

4-1 Heat Category table using WBGT for training work-rest times and water intake based on Dept of the Army TB Med 507 (2003) 
4-2 Fire danger categories with live-fire training restrictions and fire-fighting requirements, with the KBDI range used in this study for each category

4-3 Average number of days per year with calculated WBGT in the five heat categories (with temperatures shown) for each installation. The "Observed Data" column uses the daily temperatures, dewpoint, and wind speeds over 19791999 , the projected columns (right three) used added temperature changes of 1.8, 3.6, and $5.4^{\circ} \mathrm{F}$

4-4 Average number of days per year with calculated KBDI in the four categories from Tbl.4-1 for the example installations. The "Observed Data" column (uses the daily recorded temperatures and precipitation over 1979-1999, the projected columns (right three) used added temperature changes of 1.8, 3.6, and $5.4^{\circ} \mathrm{F}$ 


\section{Preface}

This study was conducted for Headquarters, U.S. Army Corps of Engineers (HQUSACE) under Project 622720A896, "Environmental Quality Guidance," Work Package "Integrated Climate Assessment for Army Enterprise Planning," Work Unit L4F5G1, "Forecast Future Climate/Weather." The technical monitor was Ms. Sarah Harrop, Headquarters, Department of the Army (HQDA).

The work was performed by the Terrestrial and Cryospheric Sciences Branch (CEERD-RRG) of the Research and Engineering Division (CEERDRR), U.S. Army Engineer Research and Development Center, Cold Regions Research and Engineering Laboratory (ERDC-CRREL). At the time of publication, CDR J. D. Horne, USN (Ret) was Chief, CEERD-RR, and Acting Chief, CEERD-RRG. The Deputy Director of ERDC-CRREL was Dr. Lance Hansen, and the Director was Dr. Joseph L. Corriveau.

COL Bryan S. Green was Commander of ERDC, and Dr. David W. Pittman was the Director. 
THIS PAGE INTENTIONALLY LEFT BLANK 


\section{Introduction}

\subsection{Background}

Although different climate models make a wide range of climate projections, all climate models reflect a global average warming trend in temperatures over both land and oceans. Moreover, since the $\mathrm{CO}_{2}$ concentration currently in the earth's atmosphere has an expected lifetime of 50 years or more, regardless of future emissions, much of this warming trend (and associated global sea level rise) is considered to be "locked in" to continue for the next 100 years. Global warming trends have the potential to negatively affect Army installations and their abilities to cost effectively complete their missions in the areas of stationing, operations, training, maintenance, and resource management. While the impacts of climate change on the Army' military mission may not yet be measurably significant, it is anticipated that, over the coming decades, the effects of climate change and their associated costs will increase.

This project was undertaken to analyze projections of future climate change derived from scenarios of greenhouse gas (GHG) emissions (carbon dioxide, methane, etc.), based on expected trends involving the expansion or reduction of fossil-fuel use. This report focuses specifically on the climate change projections to summarize emission scenarios and global and regional models, and to explain how climate projections for specific Army installations are used to generate specific projections of impacts on Army installation ranges and training activities.

\subsection{Objectives}

The overall objective of this project was to generate projections of future climate change based on expected growth or reduction trends in fossil-fuel use. The specific objective of this work was to describe those climate change projections and how those projections will impact the ranges and training activities at seven Army installations. 


\subsection{Approach}

The objectives of this work were accomplished in the following steps:

1. A review of well-documented and reviewed Global Climate Model (GCM) and Resource Capability Model (RCM) projections was done to establish inputs to be used to generate local climate impacts for the example installations.

2. Statistical downscaling based on GCM projections was applied to make projections of future climate impacts.

3. Climate and emission scenarios used by the scientific community were reviewed and three scenarios were selected for use in calculating projections.

4. Calculations were done to determine specific projected climate impacts on each of seen selected Army installations for two climate-related indices (heat and fire risk/drought) that are indicators of restrictions on training.

\subsection{Mode of technology transfer}

It is anticipated that the results of this work will be used to expand the observed data analysis from pointwise weather station data to use of the Continental United States (CONUS) wide data that will allow for the analysis of the CONUS-wide thresholds of temperature and precipitation events and include the impact of climate projections on a more comprehensive scope. 


\section{Climate Models Overview}

This work uses three spatial scales of climate models and projections: (1) global climate models (GCMs), (2) regional climate models (RCMs), and (3) local climate models (LCMs). The following sections briefly describe each model type, how the data are used in developing projections of the risks, potential impacts of climate change on Army installations, and the uncertainty in climate projections associated with each model.

This study generally drew its inputs from well-documented and reviewed GCM and RCM projections published by climate research institutions external to this project such as the National Oceanic and Atmospheric Administration (NOAA) and the National Aeronautics and Space Administration (NASA). These inputs were used to generate local climate impacts for the example installations.

\subsection{GCMs}

GCMs (also known as "general circulation models") have been developed by research institutions and agencies from multiple nations, including the United States (NOAA, National Centre for Atmospheric Research [NCAR,] NASA), United Kingdom (UK Met Office/Hadley Center), the European Center, and Australia (Commonwealth Scientific and Industrial Research Organization [CSIRO]). These models share some common features, such as equations for heat, moisture, and winds in the atmosphere, ocean temperature, salinity, and currents. These models can produce simulations of present-day or recent climate conditions (e.g., through the $20^{\text {th }}$ century) with varying degrees of accuracy. These models each have representations of different regional phenomena such as tropical precipitation, arctic ice cover, or snow cover that also vary in accuracy to observed climate. The U.S. Department of Energy's Coupled Model Intercomparison Project (CMIP) created an archive of international GCM results to facilitate the validation and comparison of these models. The CMIP- 3 and CMIP- 5 model archives contain the climate model projections for the scenarios used in this project.

GCMs represent the effects of GHG concentrations in the atmosphere mostly through their effect on the infrared radiation absorption. Water vapor is the most abundant GHG, and its concentration in the atmosphere depends strongly on air temperature and the hydrologic cycle. The models usually account for the concentrations of carbon dioxide, water vapor, me- 
thane, ozone, nitrogen oxides, and some chlorofluorocarbons (CFCs). Since observations of these gases show that these gases have increased over the $2 \mathrm{O}^{\text {th }}$ Century and that they are expected to continue increasing, the models include these increasing trends under the future emission scenarios described below.

In general, GCMs have horizontal spatial grids at a resolution of 1 to 4 degrees in longitude and latitude (approximately 100 to $500 \mathrm{~km}$ [62.1 to $310.7 \mathrm{mi}]$ ). The time scale of the climate averages from the GCMs is usually 1 month or longer. Since this GCM scale is considerably larger that the installations of interest, there are methods of "downscaling" the climate simulations from GCMs to create data on regional and local scales.

\subsection{RCMs and downscaling}

The climate simulations from GCMs are also used create climate projections on a finer spatial scale through two downscaling methods: RCMs and statistical downscaling. Regional models are similar to GCMs in that they produce simulations of regional weather on a finer scale than GCMs, but usually for periods shorter than the 100 years of changing climate. They are also subject to the same types of uncertainties and model-related biases as GCMs so there is a wide range of RCM simulations that produce a range of possible future climate changes. The North American Regional Climate Change Assessment Project (NARCCAP) produced RCM simulations from the GCMs with regional climate models at a $50 \mathrm{~km}(31.1 \mathrm{mi})$ resolution for the A2 emission scenario only. This work did not directly use RCM simulation results.

However, this work did use statistical downscaling based on GCM projections, but corrected by the baseline of recorded observed climate data from weather stations and other locations. This method of bias-corrected statistical downscaling (BCSD) for these GCM projections was developed by Maurer et al. (2007) using CONUS- wide data for average temperature and for precipitation over the period from 1950 through the future scenarios to 2099. It is much faster to use this method than to calculate complex RCMs, and statistical downscaled data have been produced from GCM data for most of the scenarios under the CMIP- 3 and CMIP- 5 archives. This work used the changes in the long-term averages from the BCSD data, and added them to the daily observed temperature and precipitation data from specific installations to make projections of future climate impacts. Future work is planned to develop the climate impacts for the entire CONUS-wide downscaled BCSD data. 


\subsection{LCMs and installation-specific models}

LCMs have been developed to address the needs and specific impacts for individual locations such as the Army installations used in this study. The LCMs use a range of site-specific climate data from local observations, as well as statistically-downscaled climate projections (like the BCSD projections described above) to assess the climate changes on the scale appropriate to the installation. In addition, these LCMs are used as "impact models" to calculate specific climate-related indices such as heating-degree days (HDD), cooling-degree days (CDD), a precipitation-based drought index, and the impacts of future climate changes on these indices. This work illustrates the impacts of climate change on future heat-related training restrictions by calculating a heat index and a drought index for the example installations. These LCMs are also being used in related projects to calculate other specific impacts on operations and infrastructure, such as the energy costs associated with the climate data and the availability of water resources to these installations.

\subsection{Climate and emission scenarios}

GHG emission scenarios created by the scientific community and used by the GCMs use different possible timelines of future GHG emissions and their resulting concentrations in the atmosphere through the year 2100. The scenarios each follow a different "story line" of fossil-fuel and nonfossil-fuel use, population growth, industrial aerosols, and other factors in the scenarios' emissions. The creators of the scenarios used in the Intergovernmental Panel on Climate Change (IPCC) Fourth Assessment Report (IPCC, 2007) and in the CMIP -3 GCMs (Nakicenvoic et al. 2000) consider each timeline to be equally plausible and possible. The scenarios from the CMIP-3 include these two frequently-used examples:

- A2: High-Emission Scenario. This scenario considers increases in $\mathrm{CO}_{2}$ emissions (or equivalent $\mathrm{CO}_{2}$ amounts) from 350 to 870 ppmv by year 2100 based on fossil-fuel growth. This has been called the "business-asusual" scenario since it most closely describes recent emissions trends.

- A1B: Medium-Emission Scenario: This scenario considers increases in $\mathrm{CO}_{2}$ emissions from 350 to 720 ppmv, with some reductions in $\mathrm{CO}_{2}$ emissions beginning around 2050.

- B1: Lower-Emission Scenario. This scenario considers increases in $\mathrm{CO}_{2}$ emissions from 350 to 550 ppmv by 2100 , with significant reductions in $\mathrm{CO}_{2}$ emissions beginning around 2050 from nonfossil-fuel energy sources. Figure 2-1 shows these emissions paths. 
More recently, the scenarios used in the projections for the IPCC Fifth Assessment Report (in progress) have been defined differently from those in CMIP-3. These scenarios have been labeled according to the Representative Concentration Path (RCP) leading to the equivalent increase in infrared radiative forcing at the surface, such as:

- $\mathrm{RCP}$ 4.5: Emission path leading to $4.5 \mathrm{~W} \mathrm{m-2}$ radiative forcing (similar to the B1 low-emission scenario)

- RCP 6.0: Emission path leading to $6.0 \mathrm{~W}$ m-2 radiative forcing (similar to the A1B medium-emission scenario)

- RCP 8.5: Emission path leading to $8.5 \mathrm{~W} \mathrm{m-2}$ radiative forcing (similar to the previous A2 high-emission scenario).

\subsection{Climate projections from emission scenarios}

Climate modelers develop climate projections for each scenario for the $20^{\text {th }}$ and $21^{\text {st }}$ Centuries by incorporating the trends in GHG concentrations into their GCMs. These long simulations are usually first initialized from a "pre-industrial" state with $\mathrm{CO}_{2}$ concentrations starting at about $180 \mathrm{ppmv}$ in the year 1870, and then simulate forward to the present-day (c. 2000) with observed $\mathrm{CO}_{2}$ concentration trends (and other effects such as volcanic and industrial sulfate aerosols and solar variability). This present-day model state is then used to initiate the future GHG emission scenarios.

Because the GCMs from different institutions vary widely in their numerical approaches to modeling phenomena such as clouds, ocean circulation, snow and ice cover, the results of the climate projections vary considerably. Figure 2-1 shows that, for the A2 scenario, the global average temperature change ranges between GCMs from $2{ }^{\circ} \mathrm{C}\left(3.6^{\circ} \mathrm{F}\right)$ to over $5{ }^{\circ} \mathrm{C}\left(9^{\circ} \mathrm{F}\right)$ in 2100 , and the $\mathrm{B} 1$ scenario ranges from 1 to $3{ }^{\circ} \mathrm{C}\left(1.8\right.$ to $\left.5.4^{\circ} \mathrm{F}\right)$ in 2100.

These results vary even more widely on the local scale, considering that the range of local variability that can affect the climate on scales is smaller than the GCM grid size. This assessment of the impacts of climate change on the local scale considers:

1. The range of climate model results from multiple GCMs for a single emission scenario

2. The multiple emission scenarios with possible future trends

3. The range of variability in local climate as compared to the larger-scale average climate. 
Figure 2-1. Sequence (top to bottom) of the creation of climate projections. Scenarios of GHG emissions (top) are created by scientific committees based on fossil-fuel use and other trends. GCMs (center) are used to simulate climate change under increasing GHGs, and create globalscale projections (bottom) of temperature change, sea level rise and other variables.

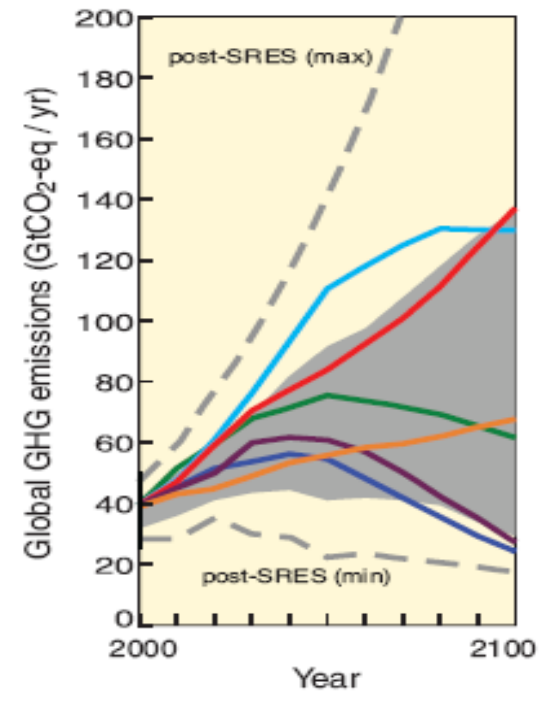

a.

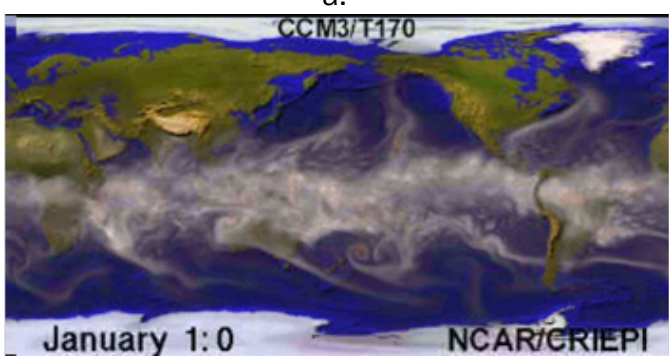

b.

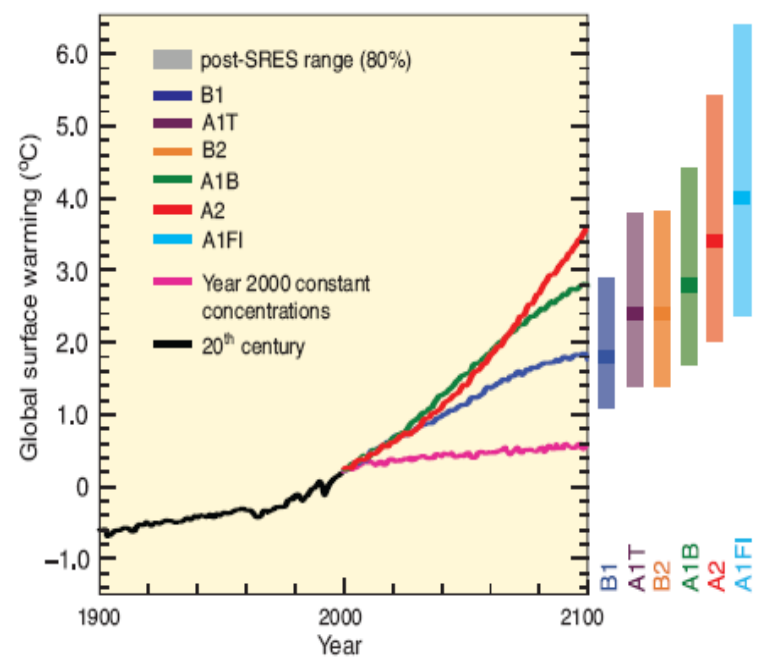

c.

Adapted from the IPCC (2007) 


\subsection{Uncertainties and agreement in climate projections}

Some uncertainties are inherent in any numerical climate model (global or regional) and in all climate projections. An important distinction to make is between climate projections and climate predictions. Climate projections are possible outcomes that could occur if the GHG concentrations follow one of the emission scenarios. There is no assumption that either the A2 or B1 scenario is more likely than any other future path; they are simply two plausible possibilities. The future trends in GHG emissions and climate that will eventually occur may not match any single scenario exactly. The global-scale factors and policies that might influence future emissions are not reliably predictable and there is no direct method to calculate or assign the probability of any one scenario.

Climate predictions (also called "forecasts"), by contrast, are based on an initial starting point of what is most likely to occur over a specific forecast timeline, such a seasonal forecast. This work is not concerned with climate prediction or forecasting. For climate projections, however, some variables have either greater or lesser uncertainty in the projections based on their natural variability on the spatial scale of installations. Complex and intermittent phenomena (like clouds) vary on scales smaller than GCM grid cells so different GCMs represent these processes with varying methods. The IPCC has represented "uncertainty" in the GCM projections on the regional scale by the relative agreement across the GCMs for any single emission scenario.

Based on the IPCC assessment (Christensen et al. 2007) and related GCM comparison studies (Walsh et al. 2008), the relative certainty (or GCM agreement) for different variables may be summarized as:

- greater certainty or agreement:

- air temperature (at the surface, when averaged over more than 10 years)

- increasing number and severity of high-heat events and droughts

- longer duration of warm-season weather, and shorter winter season

- shorter duration of snow cover and ice cover on lakes

○ increasing sea surface temperature

- warming permafrost in arctic and subarctic regions

$\circ$ rising sea level (on the global scale)

- less certainty or agreement:

$\circ$ precipitation (varying regionally, as a long-term average) 
- soil moisture

- mean streamflows (regionally)

o snowfall amounts in winter storms

- low certainty:

$\circ$ changes in wind speed and direction

o changes in frequency and intensity of severe storms

- cloud cover

- relative humidity at the surface

- solar radiation at surface. 


\section{Climate Projections and Impacts}

\subsection{Overview of climate projections}

A review of the CONUS-wide pattern of climate change projections from the GCMs (from the U.S. National Climate Assessment) reveals some overall trends in temperature and precipitation (Figure 3-1):

1. Average temperatures increase between 3 and $8{ }^{\circ} \mathrm{F}\left(1.7\right.$ and $\left.4.4{ }^{\circ} \mathrm{C}\right)$ for the lower and higher emission scenarios, with the largest warming in northern Alaska

2. Precipitation increasing in the northern tier of the United States, and decreasing in the southern tier, primarily in the U.S. Southwest.

Increased temperatures give the atmosphere greater capacity for water vapor content and transport. The consequent increased availability of precipitable water vapor for storm events is one of the climate phenomena simulated by GCMs and RCMs. The precipitation changes represent an overall acceleration of the hydrologic cycle, which includes greater evaporation in the source regions (tropics and subtropics) and greater precipitation in the sink regions (subarctic to arctic).

The majority of the contiguous United States in the mid-latitudes, including these regions of greater and lesser precipitation, is likely to experience a variable range of impacts on the scale of wet and dry seasons, with increasing precipitation from individual storm events. These changes are expected to cause a number of associated trends in related climate phenomena:

1. Greater precipitation from individual storm events and possible increases in storm intensity associated with warmer temperatures and increased moisture

2. Increased risks of flooding from individual or sequences of storm events

3. Increased risk of severe storm damage from winds

4. Shorter winters, including shorter duration of snow cover and frozen ground, ice cover on lakes and rivers, and a shift from snow to rain for the transition periods in the winter-to-spring and fall-to-winter "shoulder" seasons

5. Extended duration of season of high to extreme heat and drought, particularly for interior and southern United States

6. Coastal impacts associated with sea level rise and tropical storm events, such as inundation, erosion, and tidal surge damage. 
Figure 3-1. Upper: Projected change in air temperature $\left({ }^{\circ} \mathrm{F}\right)$ between $1970-1999$ and $2071-$ 2099 for the B1 (lower emission) and the A2 (higher emissions) scenarios. (Lower plot) Projected change in seasonal precipitation (\%) in the A2 scenario, averaged over multiple GCMs.

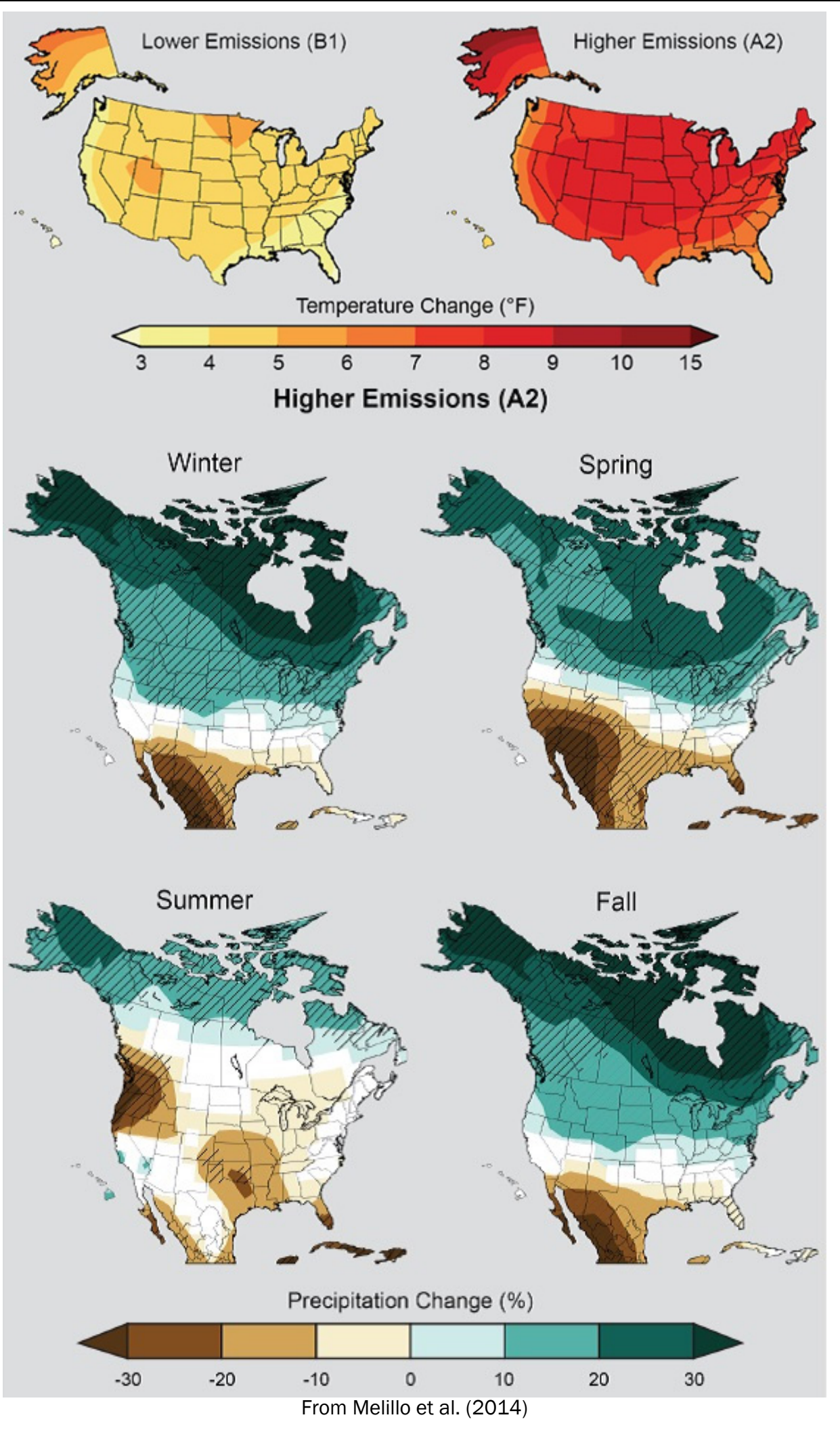




\subsection{Downscaled climate projections for regions and installations}

This first year of the study primarily used the climate change projections under the A2 scenario to compute the impacts on climate-related indices for seven sample installations: (1) Fort Riley, KS, (2) Joint Base Lewis-McCord, WA, (3) Fort Bliss, TX, (4) Fort Bragg, NC, (5) Fort Drum, NY, (6) Schoefield Barracks-Wheeler Army Airfield (AAF), HI, and (7) Fort Wainwright (AK). This section describes the climate projections used for these locations and the range of climate projections across different models.

This study used the BCSD data for CONUS locations from the CMIP 3 GCMs (Maurer et al. 2007) as the primary source for climate projections for the period from present to 2099 for the computing indices. These data are on a 1/8-degree latitude-longitude grid ( $12 \times 12 \mathrm{~km}[7.5 \times 7.5 \mathrm{mi}])$. For each installation, the projection data for the grid cell closest to the installation location were collected for the A2, B1, and A1B scenarios. In most cases, this work uses use the A2 (high-emission) scenario first, as it illustrates the largest-magnitude possible impact, while the $\mathrm{A} 1 \mathrm{~B}$ and $\mathrm{B} 1$ scenarios are similar, but smaller-magnitude responses.

In Figure 3-2, which shows the annual temperatures over 1950 to 2099 for the A2 and B1 scenarios for Fort Bragg, the two scenarios diverge significantly after about 2050. The A2 scenario shows an increase of about $9{ }^{\circ} \mathrm{F}$ $\left(5{ }^{\circ} \mathrm{C}\right)$ between 1950 and 2099 for the average of all $36 \mathrm{GCM}$ projections, while the GCMs span a range of $15^{\circ} \mathrm{F}\left(8.3^{\circ} \mathrm{C}\right)$ by 2099.

The change in air temperature (at the surface) and the relative change in average precipitation (as a percentage of the mean) were computed for each installation location, for each of the GCMs, between the periods 1980-1999, 2020-2039, 2040-2059, and 2080-2099. Figure 3-3 shows the combined temperature change $\left({ }^{\circ} \mathrm{C}\right)$ and precipitation change (\%) for Fort Bliss at two periods for the A2 scenario, which show the scatter of the GCMs projections at this spatial scale. For the 2080 period, precipitation change varies across the downscaled GCMs from $-40 \%$ to $+40 \%$, while the temperature increases from 3 to $6^{\circ} \mathrm{C}\left(5.4\right.$ to $\left.10.8^{\circ} \mathrm{F}\right)$. 
Figure 3-2. Average air temperature $\left({ }^{\circ} \mathrm{F}\right)$ for Fort Bragg, as a 5-year running mean over 1950 2099 for the A2 and B1 scenarios, average over the 36 downscaled GCM simulations. The upper and lower lines show the maximum and minimum annual temperatures of the $36 \mathrm{GCMs}$.

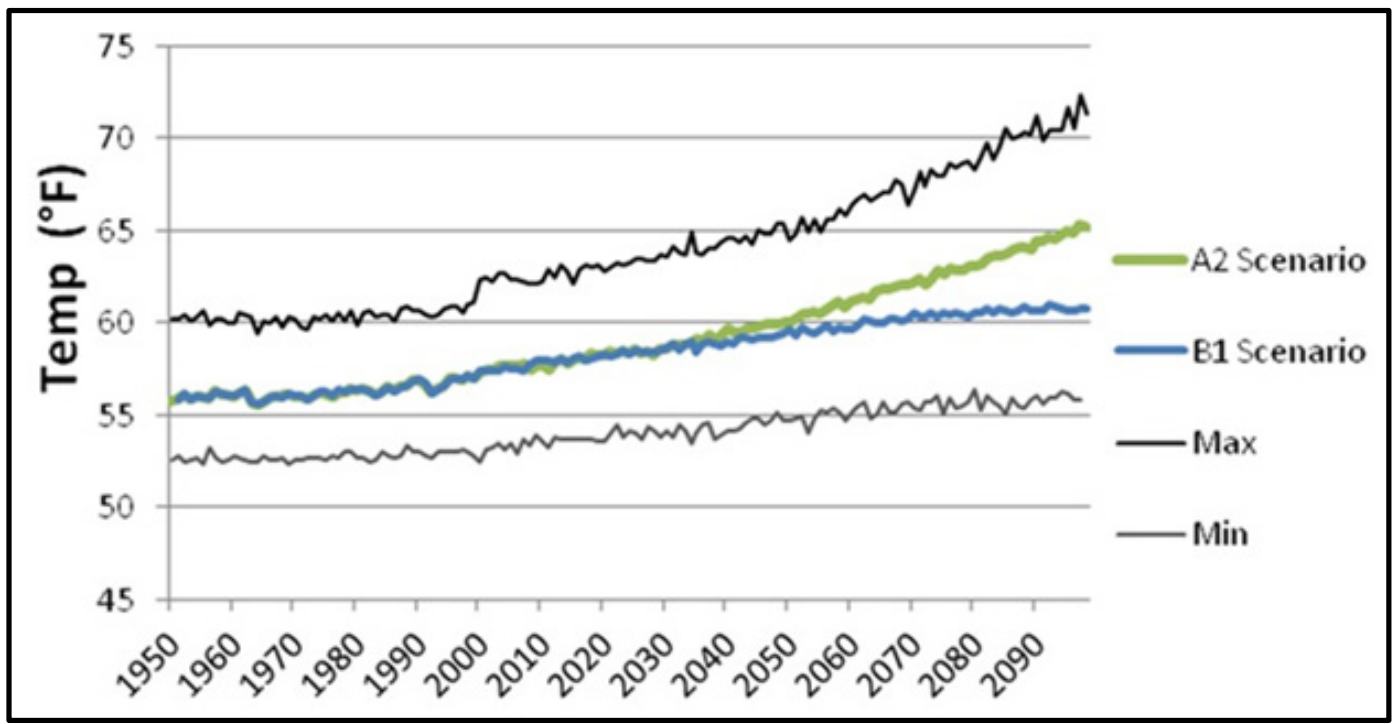

Figure 3-3. Projected change in air temperature change $\left({ }^{\circ} \mathrm{C}\right)$ versus precipitation change $(\%)$ for Fort Bliss, TX, for each of $36 \mathrm{GCMs}$ from the downscaled CMIP-3 archive for the A2 (high-emission) scenario, between 1980-1999 and 2040-2060 (black points) and 2080-2090 (blue points).

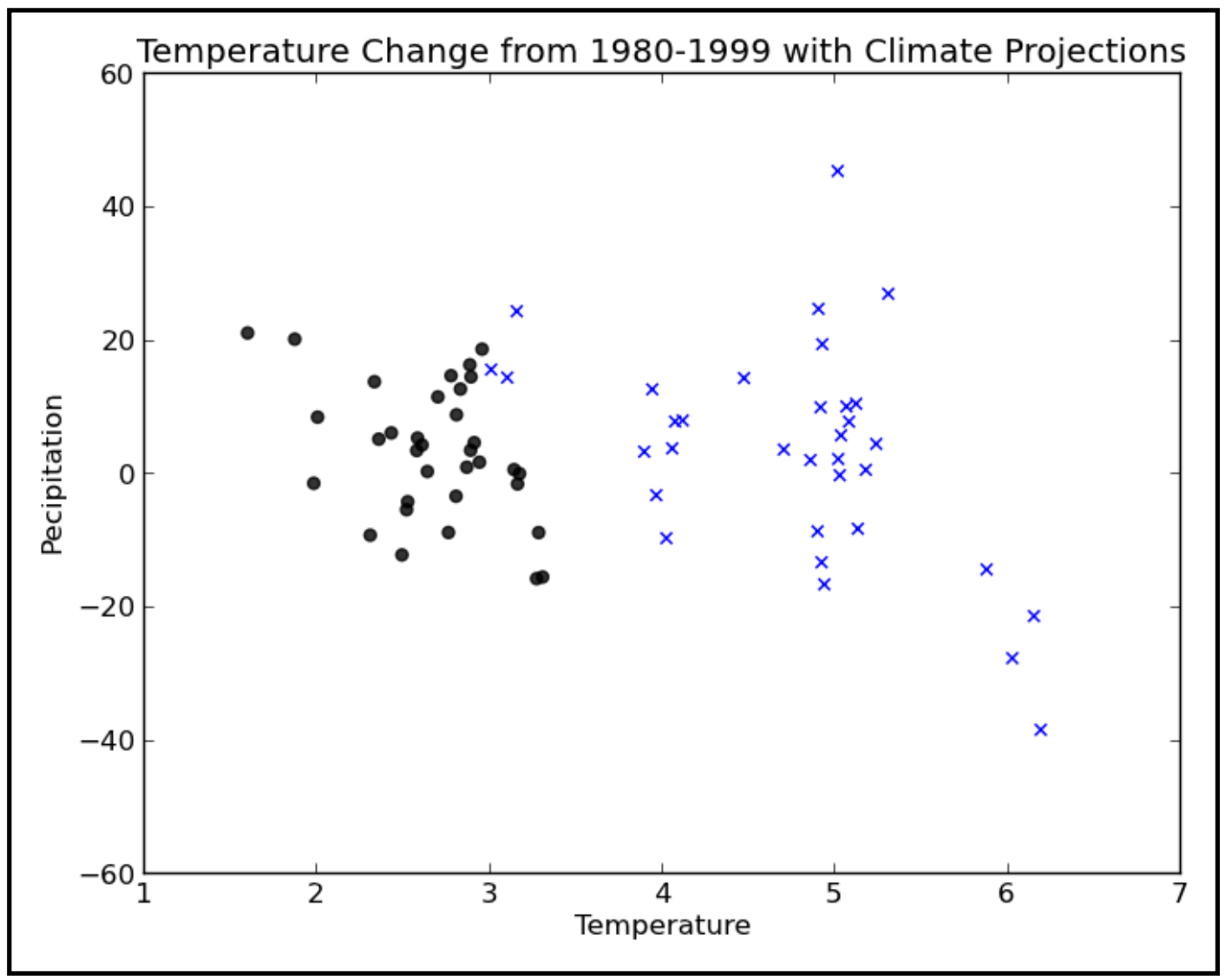


Table 3-1 lists the average temperature and precipitation changes for the A2 scenario for the 2050 and 2080 timeframes for the seven sample installations, averaged over all of the $36 \mathrm{GCM}$ projections. These data show that the installations generally warm in the range of 2 to $5^{\circ} \mathrm{C}\left(3.6\right.$ to $\left.9^{\circ} \mathrm{F}\right)$ for 2080 , and that the precipitation increases on average $3 \%$ to $20 \%$. These temperature increases are added to the observed temperatures for station data in computing heat indexes for the installations in the next chapter.

Table 3-1. Projected changes in air temperature $\left({ }^{\circ} \mathrm{C}\right)$ and precipitation (\%) for 7 example installations, averaged over 36 simulations from the downscaled CMIP-3 archive for the A2 (high-emission) scenario, between 1980-1999 and 2050 and 2080.

\begin{tabular}{|l|c|c|c|}
\hline \multicolumn{1}{|c|}{ Location } & Parameter & 2050 & 2080 \\
\hline \multirow{2}{*}{ Fort Bliss } & $\Delta \mathrm{T}\left({ }^{\circ} \mathrm{C}\right)$ & 2.7 & 4.8 \\
\cline { 2 - 4 } & $\Delta \mathrm{P}(\%)$ & 3.1 & 3.3 \\
\hline \multirow{2}{*}{ Fort Bragg } & $\Delta \mathrm{T}\left({ }^{\circ} \mathrm{C}\right)$ & 2.3 & 3.9 \\
\cline { 2 - 4 } & $\Delta \mathrm{P}(\%)$ & 11.5 & 13.3 \\
\hline \multirow{2}{*}{ Fort Drum } & $\Delta \mathrm{T}\left({ }^{\circ} \mathrm{C}\right)$ & 2.3 & 4.4 \\
\cline { 2 - 4 } & $\Delta \mathrm{P}(\%)$ & 12.4 & 17.7 \\
\hline \multirow{2}{*}{ Moint Base (JB) Lewis- } & $\Delta \mathrm{T}\left({ }^{\circ} \mathrm{C}\right)$ & 1.8 & 3.4 \\
\cline { 2 - 4 } & $\Delta \mathrm{P}(\%)$ & 9.6 & 14.2 \\
\hline \multirow{2}{*}{ Fort Riley } & $\Delta \mathrm{T}\left({ }^{\circ} \mathrm{C}\right)$ & 2.5 & 4.6 \\
\cline { 2 - 4 } & $\Delta \mathrm{P}(\%)$ & 8.8 & 9.4 \\
\hline \multirow{2}{*}{ Fort Wainwright } & $\Delta \mathrm{T}\left({ }^{\circ} \mathrm{C}\right)$ & 2.2 & 4.5 \\
\cline { 2 - 4 } & $\Delta \mathrm{P}(\%)$ & 10.5 & 21.0 \\
\hline \multirow{2}{*}{ Schoefield -Wheeler AAF } & $\Delta \mathrm{T}\left({ }^{\circ} \mathrm{C}\right)$ & 1.1 & 2.3 \\
\cline { 2 - 4 } & $\Delta \mathrm{P}(\%)$ & 2.5 & 5.0 \\
\hline
\end{tabular}




\section{Projected Climate-Related Indices}

\subsection{Heat restricted training days}

Two indices that have the potential to affect the metrics of available training days on ranges are: (1) the number of days with heat-related training restrictions and (2) the number of days with high fire risk for live-fire training. These two indices are both computed from daily temperature and other observed data for installations, and can also be readily computed from projections of temperatures and precipitation from climate models for future climate scenarios.

Heat-stress days are computed from the maximum daily wet bulb-black globe temperature (WBGT), which combines the maximum wet bulb temperature $\left(\mathrm{T}_{\mathrm{wb}}\right)$, ambient air temperature $\left(\mathrm{T}_{\mathrm{air}}\right)$, and temperature measured inside a black globe in the incident sunlight $\left(\mathrm{T}_{\mathrm{g}}\right)$ :

$$
\text { WBGT }=T_{\text {wbgt }}=0.7 \mathrm{~T}_{\mathrm{wb}}+0.2 \mathrm{~T}_{\mathrm{g}}+0.1 \mathrm{~T}_{\text {air }}
$$

While WBGT can be measured on-site at installations, this work computed WBGT from the separate temperatures above as functions of the daily maximum temperature, humidity, wind speed, and solar radiation for the location of interest. Brown et al. (2014) describes the equations used for black globe temperature $\mathrm{T}_{\mathrm{g}}$.

The exact method for computing the wet bulb temperature, $T_{\mathrm{wb}}$, from the ambient air temperature and relative humidity is nonlinear and can be done using a meteorological skew-T diagram. This work computed a lookup table to list $\mathrm{T}_{\mathrm{wb}}$ for the range of temperature and humidity. Figure 4-1 shows the values of $\mathrm{T}_{\mathrm{wb}}$ for this range.

The WBGT is used in determining when soldiers are potentially at risk of heat-related illness in training based on the guidance of Army Technical Bulletin Medical 507 (HQDA 2003). The increasing Heat Category 1 through 5 corresponds to the WBGT increasing from $78^{\circ} \mathrm{F}\left(25.6^{\circ} \mathrm{C}\right)$ (Cat 1) to $>90^{\circ} \mathrm{F}\left(>32.2^{\circ} \mathrm{C}\right)$ (Cat 5$)$. 
Figure 4-1. Graph of wet bulb temperature $\left(\operatorname{Twb}^{\circ}{ }^{\circ} \mathrm{F}\right)$ as function of air temperature (Tair) and relative humidity (\%) at mean sea level used in the calculation of WBGT.

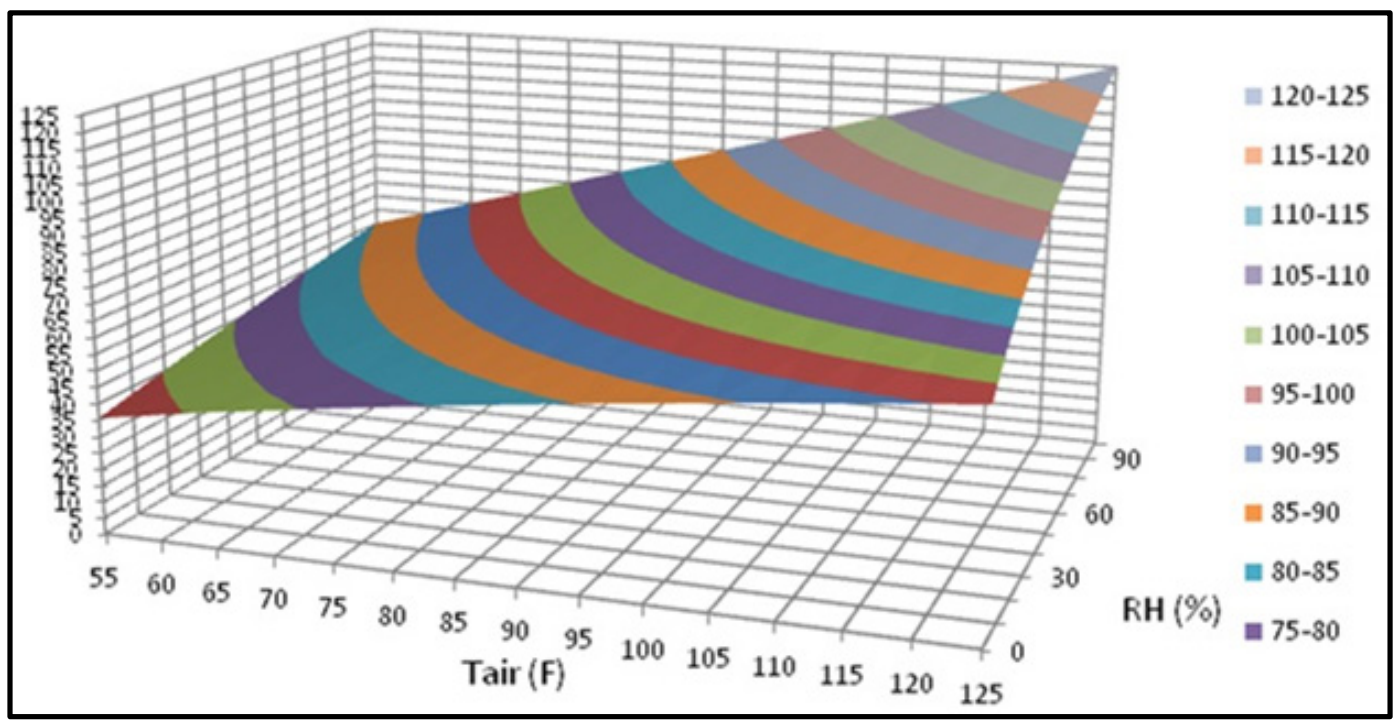

Table 4-1. Heat Category table using WBGT for training work-rest times and water intake based on Dept of the Army TB Med 507 (2003).

\begin{tabular}{|c|c|c|c|c|c|c|c|}
\hline \multirow{2}{*}{$\begin{array}{c}\text { Heat } \\
\text { Category }\end{array}$} & \multirow{2}{*}{$\begin{array}{c}\text { WBGT } \\
\text { Index, } \mathrm{F}^{\circ}\end{array}$} & \multicolumn{2}{|c|}{ Easy Work } & \multicolumn{2}{c|}{ Moderate Work } & \multicolumn{2}{c|}{ Hard Work } \\
\cline { 3 - 8 } & Work/Rest & $\begin{array}{c}\text { Water } \\
\text { Intake } \\
(Q t / H)\end{array}$ & Work/Rest & $\begin{array}{c}\text { Water } \\
\text { Intake } \\
(Q t / H)\end{array}$ & Work/Rest & $\begin{array}{c}\text { Water } \\
\text { Intake } \\
(Q t / H)\end{array}$ \\
\hline 1 & $78^{\circ}-81.9^{\circ}$ & NL & $1 / 2$ & NL & $3 / 4$ & $40 / 20 \mathrm{~min}$ & $3 / 4$ \\
\hline $\begin{array}{c}2 \\
\text { (GREEN) }\end{array}$ & $82^{\circ}-84.9^{\circ}$ & $\mathrm{NL}$ & $1 / 2$ & $50 / 10 \mathrm{~min}$ & $3 / 4$ & $30 / 30 \mathrm{~min}$ & 1 \\
\hline $\begin{array}{c}3 \\
\text { (YELOW) }\end{array}$ & $85^{\circ}-87.9^{\circ}$ & $\mathrm{NL}$ & $3 / 4$ & $40 / 20 \mathrm{~min}$ & $3 / 4$ & $30 / 30 \mathrm{~min}$ & 1 \\
\hline $\begin{array}{c}4 \\
(\text { RED })\end{array}$ & $88^{\circ}-89.9^{\circ}$ & $\mathrm{NL}$ & $3 / 4$ & $30 / 30 \mathrm{~min}$ & $3 / 4$ & $20 / 40 \mathrm{~min}$ & 1 \\
\hline $\begin{array}{c}5 \\
\text { (BLACK) }\end{array}$ & $>90^{\circ}$ & $50 / 10 \mathrm{~min}$ & 1 & $20 / 40 \mathrm{~min}$ & 1 & $10 / 50 \mathrm{~min}$ & 1 \\
\hline
\end{tabular}

The number of days with WBGT within each heat category in Table 4-1 were computed for the example installations using observed weather records for the period 1970-1999. While many CONUS locations experience high temperatures $>80^{\circ} \mathrm{F}\left(>26.7^{\circ} \mathrm{C}\right)$, dewpoint temperatures usually must be near $80{ }^{\circ} \mathrm{F}\left(26.7^{\circ} \mathrm{C}\right)$ for the corresponding WBGT to also be $>80^{\circ} \mathrm{F}\left(>26.7^{\circ} \mathrm{C}\right)$. Figure 4-2 shows the average days each month with air temperatures $>90{ }^{\circ} \mathrm{F}\left(>32.2{ }^{\circ} \mathrm{C}\right)$ for Fort Riley, KS and Fort Bliss, TX. In spite of the fact that Fort Bliss experiences over 25 days per year with air temperature $>90{ }^{\circ} \mathrm{F}\left(>32.2^{\circ} \mathrm{C}\right)$, it experiences only 2 days per year with WBGT $>85^{\circ} \mathrm{F}$ $\left(>29.4{ }^{\circ} \mathrm{C}\right)$. Fort Riley, KS, which has fewer days than Fort Bliss with the air temperature $>90{ }^{\circ} \mathrm{F}\left(>32.2{ }^{\circ} \mathrm{C}\right)$, has 10 days with WBGT $>85^{\circ} \mathrm{F}\left(>29.4{ }^{\circ} \mathrm{C}\right)$. This sensitivity of the heat-risk index to humidity is also a consideration for 
the projections of climate change and their impact on the heat-affected days for these installations, as is shown later in this report.

Figure 4-2. Average number of days per month with air temperatures $>90^{\circ} \mathrm{F}\left(>32.2^{\circ} \mathrm{C}\right)$ from daily maximum temperatures for Fort Riley KS and Fort Bliss, TX over 1970-1999.

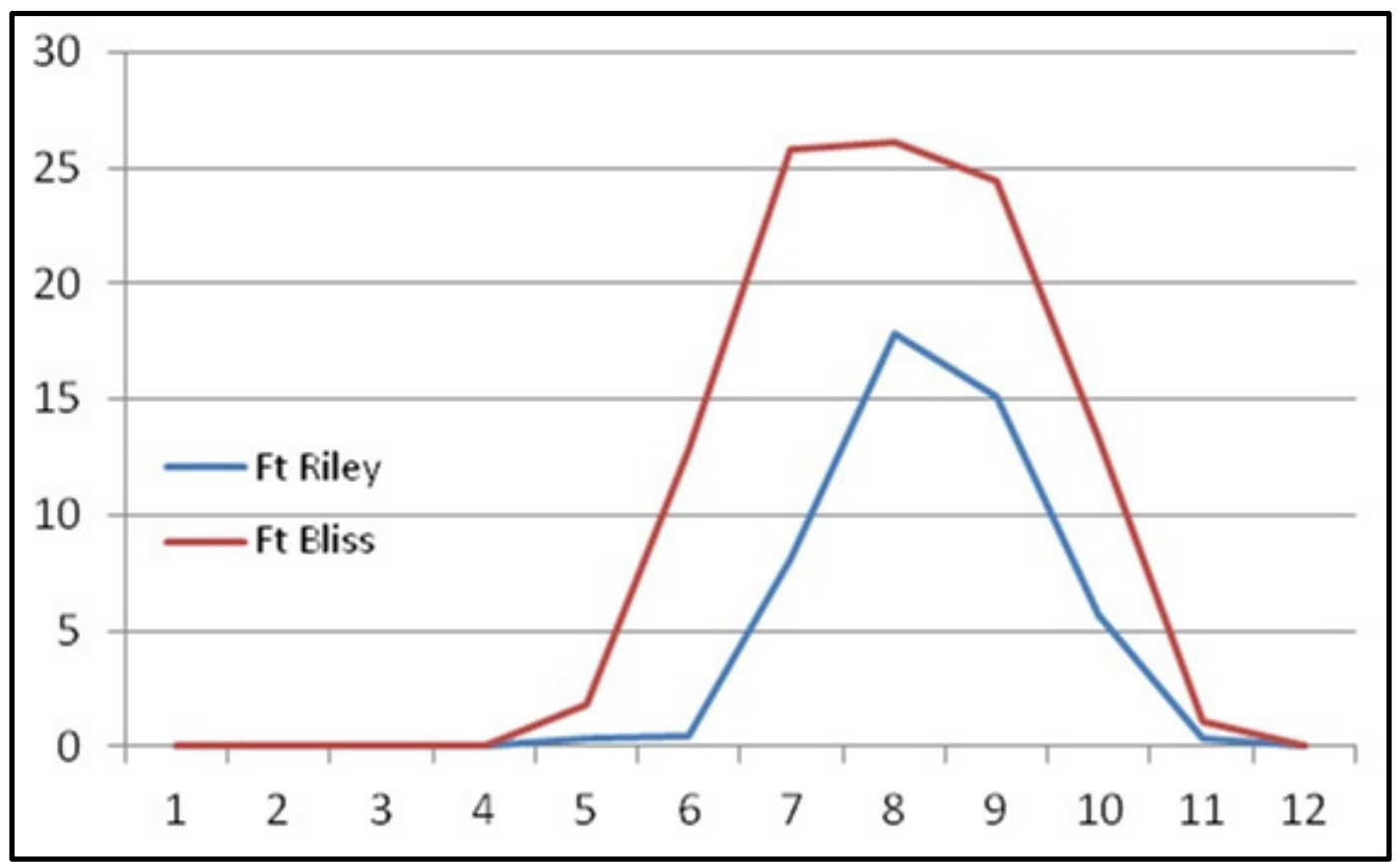

\subsection{Fire risk days}

Similar to the heat index restrictions on training, the days with a high drought index have been used to regulate the restrictions on types of livefire training on Army ranges, either by regulating the availability of firefighting manpower, or by restricting live-fire training in the event of severely dry conditions. In this study, the fire risk index is computed using the Keetch-Byram Drought Index (KBDI), designated $Q$, by incrementing the index $d Q$ using the daily maximum air temperature $\left(\mathrm{T}_{\max }\right)$ and daily precipitation, $P$. The formulation follows the revised and corrected English units equation of Alexander (1990) and Crane (1982) of the original Keetch and Byram (1968) index:

$$
d Q=\frac{[800-Q][0.968 \exp (0.0486 \mathrm{Tmax})-8.30] d t \times 10^{-3}}{1+10.88 \exp (-0.0441 R)}
$$

The minimum $Q$ value is kept at zero and the maximum at 800 , which indicates an 8-in. deficit in precipitation. 
The KBDI was computed for the eight example installation from their daily observed records for 1970-1999. Figure 4-3 shows the average monthly KBDI for Fort Riley, Fort Bliss, and Fort Wheeler.

Figure 4-3. Monthly average values of the KBDI from daily observations for Fort Riley, KS, Wheeler Air Force Base (AFB), HI, and Fort Bliss, TX over 1979-1999.

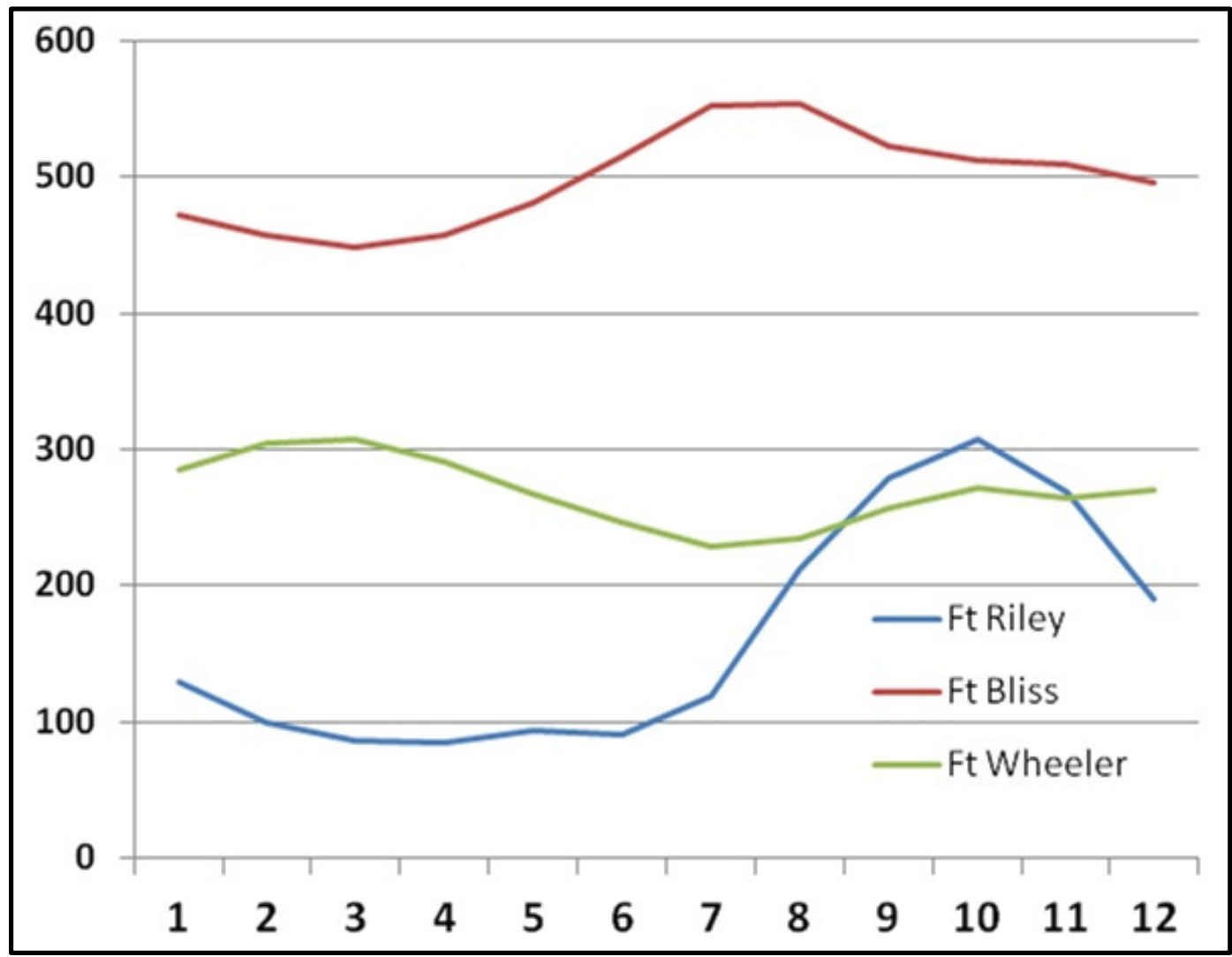

The risk of igniting fires on training ranges through live-fire training potentially increases with greater KBDI, i.e., with greater maximum daily temperatures and little or no precipitation, and which increases with duration in days. For any particular training range, there are other potential factors to consider in the risk of igniting fires through live-fire training, such as the presence or abundance of dry vegetation and persistent wetlands that may not be high risk for ignition. Therefore, the on-site determination of fire risk by firing range managers and restrictions on live-fire training are determined locally and are not based on a single factor such as KBDI.

For ranges with significant risk, Table 4-2 lists the types of restrictions in live-fire training that can be implemented based on the KBDI. The increasing risk, which is denoted by the green-to-black color scale, corresponds with increasing requirements to have a fire-fighting detail on hand. 
Table 4-2. Fire danger categories with live-fire training restrictions and fire-fighting requirements, with the KBDI range used in this study for each category.

\begin{tabular}{|l|l|l|l|l|}
\hline $\begin{array}{l}\text { Fire Danger } \\
\text { Condition }\end{array}$ & Expected Fire Behavior & Training Restrictions & $\begin{array}{l}\text { Fire-Fighting Detail } \\
\text { Requirements }\end{array}$ & $\begin{array}{l}\text { Derived } \\
\text { KBDI* }\end{array}$ \\
\hline GREEN & $\begin{array}{l}\text { Fires are difficult to start and do not } \\
\text { burn with vigor. Fires can easily be } \\
\text { controlled using direct attack. }\end{array}$ & None. & None. & 0 -300 \\
\hline AMBER & $\begin{array}{l}\text { Fires start easily and may burn } \\
\text { quickly through grass and shrub } \\
\text { fuels. Fires can be controlled using } \\
\text { direct attack, but in some } \\
\text { circumstances may require indirect } \\
\text { attack methods. }\end{array}$ & $\begin{array}{l}\text { No aerial flares outside the } \\
\text { live-fire training areas. } \\
\text { Pyrotechnics must be used } \\
\text { on roadways, tank trails, or } \\
\text { barren areas. }\end{array}$ & None. & $300-600$ \\
\hline RED & $\begin{array}{l}\text { Fires start easily, move quickly, } \\
\text { burn intensely, and may be difficult } \\
\text { to control. }\end{array}$ & $\begin{array}{l}\text { No pyrotechnics, incendiary } \\
\text { munitions, tracers. }\end{array}$ & $\begin{array}{l}10-\text {-person fire-fighting } \\
\text { detail required. } \\
\text { On-call helicopter } \\
\text { required on 20- } \\
\text { minute standby. }\end{array}$ & $600-750$ \\
\hline BLACK & $\begin{array}{l}\text { Fires start very easily and are } \\
\text { impossible to control. }\end{array}$ & $\begin{array}{l}\text { No live-fire training. No } \\
\text { pyrotechnics. Non-live-fire } \\
\text { training must be authorized } \\
\text { by the Senior Mission } \\
\text { Commander. }\end{array}$ & None. \\
\hline
\end{tabular}

\subsection{Projected climate change on heat and fire risk}

Projected future changes in temperature and precipitation have been used to calculate these two climate-related indices, WBGT and KBDI, for the sample installations in the first year of this study. The following sections give examples of these projections. Increases in air temperature by 1,2 , and $3{ }^{\circ} \mathrm{C}\left(3.6,1.8\right.$, and $\left.5.4{ }^{\circ} \mathrm{F}\right)$ have been added to the air temperature used in the formula for WBGT to calculate the number of days with heat-stress restrictions. For these projections of WBGT, the relative humidity, wind and solar inputs are left unchanged. The temperature increases are average changes for the central United States across multiple GCMs, corresponding to 10-year periods centered around 2030, 2050, and 2080.

\subsection{Heat-risk training impacts}

Figure 4-4 shows the number of days per year with WBGT in each heat category (1-5) for Fort Bliss TX, with the projected future days. The total days with all levels of heat categories increase from 94 in the observed data to 160 days per year in 2080. There are no "black flag" Category-5 days for Fort Bliss, even though it has extremely high air temperatures $\left(100{ }^{\circ} \mathrm{F}\left[37.8^{\circ} \mathrm{C}\right]\right.$ or more). The dewpoint is less than $80^{\circ} \mathrm{F}\left(26.7^{\circ} \mathrm{C}\right)$ in all recorded days for 1970-1999 so the wet bulb temperature is also less than $80^{\circ} \mathrm{F}\left(26.7^{\circ} \mathrm{C}\right)$. The number of Category 3 days increases the most by 2080, from 2 to 39 days. 
Figure 4-4. Average number of days per year with calculated WBGT in the five heat categories (with temperatures shown) for Fort Bliss, TX. The "Observed Data" column (left) use the daily temperatures, dewpoint, and wind speeds over 1979-1999, The projected columns (right three) used added temperature changes from climate models centered on years 2030,2050 , and 2080.

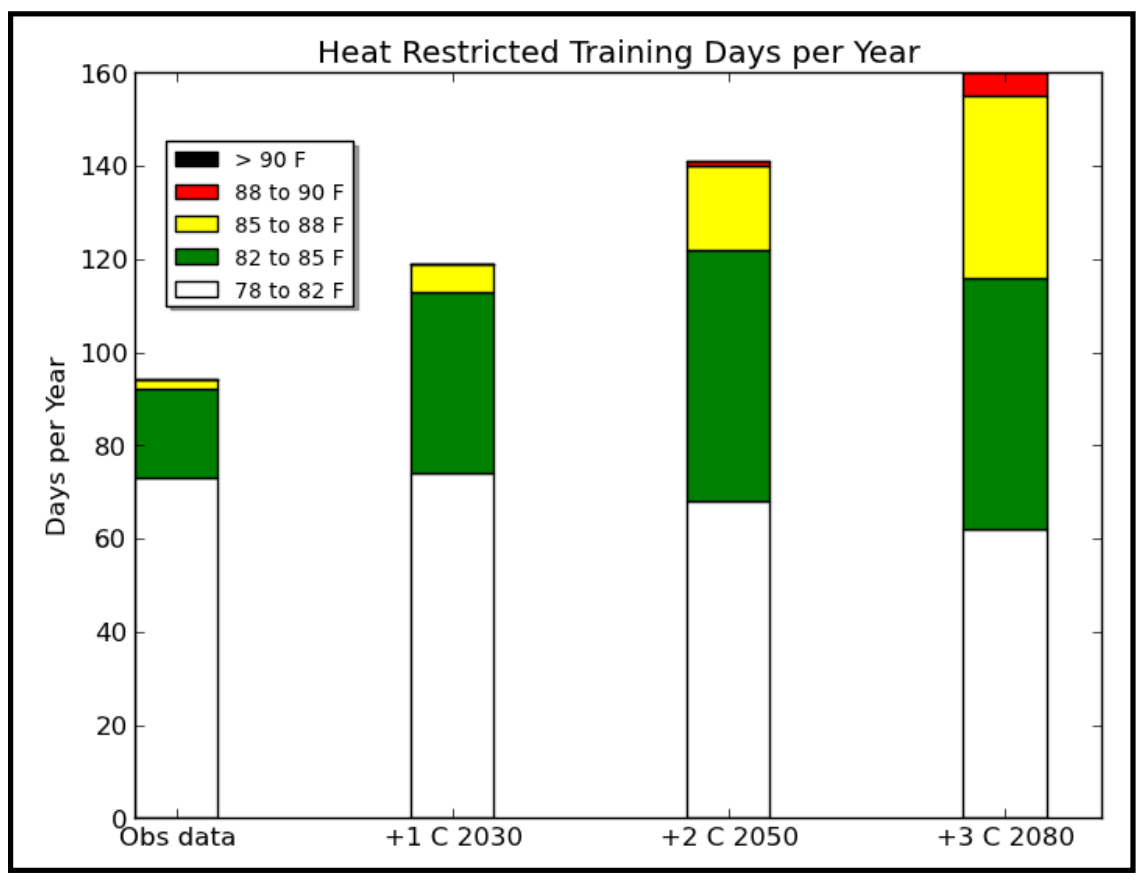

These projections of future WBGT reflect a potential for increasing risk of heat-related injury and restrictions on training activities during the maximum daytime heat. The data in Figure 4-4 does not reflect the potential impacts on nighttime or early morning training, which are less affected by the solar input, but can be affected by temperature and humidity. Both day and night training impacts are included in this set of climate-related impacts for installations.

Table 4-3 lists the number of days with each heat category of WBGT for all seven sample Army installations for the observed station data and for the projected temperature increases. Figures 4-6 to 4-12 plot these values for each installation. Of these sample installations, the location with the greatest impact on training days for the observed data is Fort Bragg, NC, which experiences high temperatures and dewpoints $>80^{\circ} \mathrm{F}\left(>26.7^{\circ} \mathrm{C}\right)$ through the summer. The projected increase in temperatures up to $5.4^{\circ} \mathrm{F}$ $\left(-14.8^{\circ} \mathrm{C}\right)$ results in a significant increase of overall heat-affected training days, even with the relative humidity kept unchanged for these projections. By contrast, Fort Bliss, TX, has high temperatures, but no increase in the highest Heat Category $5\left(>90^{\circ} \mathrm{F}\left[>32.2^{\circ} \mathrm{C}\right]\right)$ due to the fact that its dewpoints are lower than those at Fort Bragg. 
Table 4-3. Average number of days per year with calculated WBGT in the five heat categories (with temperatures shown) for each installation. The "Observed Data" column uses the daily temperatures, dewpoint, and wind speeds over 1979-1999, the projected columns (right three) used added temperature changes of $1.8,3.6$, and $5.4^{\circ} \mathrm{F}$.

\begin{tabular}{|c|c|c|c|c|c|}
\hline $\begin{array}{c}\text { Heat } \\
\text { Category }\end{array}$ & WBGT Range & Observed Data & $\begin{array}{l}\text { Observed } \\
+1.8^{\circ} \mathrm{F}\end{array}$ & $\begin{array}{l}\text { Observed } \\
+3.6^{\circ} \mathrm{F}\end{array}$ & $\begin{array}{l}\text { Observed } \\
+5.4^{\circ} \mathrm{F}\end{array}$ \\
\hline \multicolumn{6}{|c|}{ Fort Bliss } \\
\hline Cat 5 & $>90^{\circ} \mathrm{F}$ & 0 & 0 & 0 & 0 \\
\hline Cat 4 & $88-90^{\circ} \mathrm{F}$ & 0 & 0 & 1 & 5 \\
\hline Cat 3 & $85-88^{\circ} \mathrm{F}$ & 2 & 6 & 18 & 39 \\
\hline Cat 2 & $82-85^{\circ} \mathrm{F}$ & 19 & 39 & 54 & 54 \\
\hline Cat 1 & $78-82^{\circ} \mathrm{F}$ & 73 & 74 & 68 & 62 \\
\hline \multicolumn{6}{|c|}{ Fort Bragg } \\
\hline Cat 5 & $>90^{\circ} \mathrm{F}$ & 3 & 6 & 13 & 25 \\
\hline Cat 4 & $88-90^{\circ} \mathrm{F}$ & 4 & 9 & 15 & 22 \\
\hline Cat 3 & $85-88^{\circ} \mathrm{F}$ & 19 & 28 & 36 & 36 \\
\hline Cat 2 & $82-85^{\circ} \mathrm{F}$ & 35 & 36 & 36 & 33 \\
\hline Cat 1 & $78-82^{\circ} \mathrm{F}$ & 48 & 45 & 42 & 42 \\
\hline \multicolumn{6}{|c|}{ Fort Drum } \\
\hline Cat 5 & $>90^{\circ} \mathrm{F}$ & 0 & 0 & 0 & 0 \\
\hline Cat 4 & $88-90^{\circ} \mathrm{F}$ & 0 & 0 & 0 & 0 \\
\hline Cat 3 & $85-88^{\circ} \mathrm{F}$ & 0 & 0 & 0 & 2 \\
\hline Cat 2 & $82-85^{\circ} \mathrm{F}$ & 0 & 1 & 4 & 7 \\
\hline Cat 1 & $78-82^{\circ} \mathrm{F}$ & 7 & 11 & 17 & 23 \\
\hline \multicolumn{6}{|c|}{ JB Lewis-McChord } \\
\hline Cat 5 & $>90^{\circ} \mathrm{F}$ & 0 & 0 & 0 & 0 \\
\hline Cat 4 & $88-90^{\circ} \mathrm{F}$ & 0 & 0 & 0 & 0 \\
\hline Cat 3 & $85-88^{\circ} \mathrm{F}$ & 0 & 0 & 1 & 5 \\
\hline Cat 2 & $82-85^{\circ} \mathrm{F}$ & 1 & 5 & 6 & 5 \\
\hline Cat 1 & $78-82^{\circ} \mathrm{F}$ & 9 & 10 & 17 & 25 \\
\hline \multicolumn{6}{|c|}{ Fort Riley } \\
\hline Cat 5 & $>90^{\circ} \mathrm{F}$ & 0 & 1 & 4 & 10 \\
\hline Cat 4 & $88-90^{\circ} \mathrm{F}$ & 1 & 4 & 8 & 13 \\
\hline Cat 3 & $85-88^{\circ} \mathrm{F}$ & 9 & 17 & 23 & 27 \\
\hline Cat 2 & $82-85^{\circ} \mathrm{F}$ & 23 & 26 & 27 & 28 \\
\hline Cat 1 & $78-82^{\circ} \mathrm{F}$ & 38 & 38 & 38 & 38 \\
\hline \multicolumn{6}{|c|}{ Fort Wainwright } \\
\hline Cat 5 & $>90^{\circ} \mathrm{F}$ & 0 & 0 & 0 & 0 \\
\hline Cat 4 & $88-90^{\circ} \mathrm{F}$ & 0 & 0 & 0 & 0 \\
\hline Cat 3 & $85-88^{\circ} \mathrm{F}$ & 0 & 0 & 0 & 31 \\
\hline Cat 2 & $82-85^{\circ} \mathrm{F}$ & 0 & 31 & 31 & 0 \\
\hline Cat 1 & $78-82^{\circ} \mathrm{F}$ & 31 & 2 & 7 & 11 \\
\hline
\end{tabular}




\begin{tabular}{|c|c|c|c|c|c|}
\hline $\begin{array}{c}\text { Heat } \\
\text { Category }\end{array}$ & WBGT Range & Observed Data & $\begin{array}{l}\text { Observed } \\
+1.8^{\circ} \mathrm{F}\end{array}$ & $\begin{array}{l}\text { Observed } \\
+3.6^{\circ} \mathrm{F}\end{array}$ & $\begin{array}{l}\text { Observed } \\
+5.4^{\circ} \mathrm{F}\end{array}$ \\
\hline \multicolumn{6}{|c|}{ Schoefield, Wheeler AAF } \\
\hline Cat 5 & $>90^{\circ} \mathrm{F}$ & 0 & 0 & 0 & 0 \\
\hline Cat 4 & $88-90^{\circ} \mathrm{F}$ & 0 & 0 & 0 & 1 \\
\hline Cat 3 & $85-88^{\circ} \mathrm{F}$ & 0 & 1 & 3 & 13 \\
\hline Cat 2 & $82-85^{\circ} \mathrm{F}$ & 2 & 11 & 32 & 67 \\
\hline Cat 1 & $78-82^{\circ} \mathrm{F}$ & 53 & 101 & 148 & 160 \\
\hline
\end{tabular}

One consideration of these sample results is that only the temperature projections are increased - not humidity, winds, or solar radiation. The WBGT values for arid locations like Fort Bliss are very sensitive to any increase in humidity. The relative humidity at locations like Fort Bliss might change (increase or decrease) with changing climate since the warmer atmosphere holds more moisture content, but also has an increased moisture capacity before saturation. GCMs and these downscaled projections provide very uncertain estimates of changing humidity, which is highly variable on hourly and daily timescales and smaller spatial scales than temperature. Brown et al. (2104) described the impacts of changing humidity on WBGT. For this study in FY14, relative humidity remained unchanged.

\subsection{Fire risk impacts from computed drought index}

Figure 4-5 shows the number of days with the KBDI corresponding to each fire risk category in Table 4-2 (indicated by green, yellow, red, and black) for Fort Bliss, TX. The KBDI using the daily recorded temperature and precipitation are shown for the observed data. The same increases in temperature $\left(1,2\right.$, and $3{ }^{\circ} \mathrm{C}\left[3.6,1.8\right.$, and $\left.\left.5.4^{\circ} \mathrm{F}\right]\right)$ are added to the observed temperatures centered on the years 2030, 2050, and 2080. For these results, the precipitation is kept unchanged from the observed period, although there is significant spread in the projected changes in precipitation over $\pm 40 \%$.

For Fort Bliss, the number of "black" Category-4 days (highest KBDI) increase from 60 in the observed period to 85 days in 2080, while the "red" Category-3 days also increase slightly from 160 to 180 days, and the lowerrisk yellow and green category days decrease accordingly. 
Figure 4-5. Average number of days per year with calculated KBDI in the categories from

Tbl. 4-1 for Fort Bliss, TX. The "Observed Data" column (left) uses the daily recorded temperatures and precipitation over 1979-1999. The projected columns (right three) used added temperature changes from climate models centered on years 2030, 2050, and 2080.

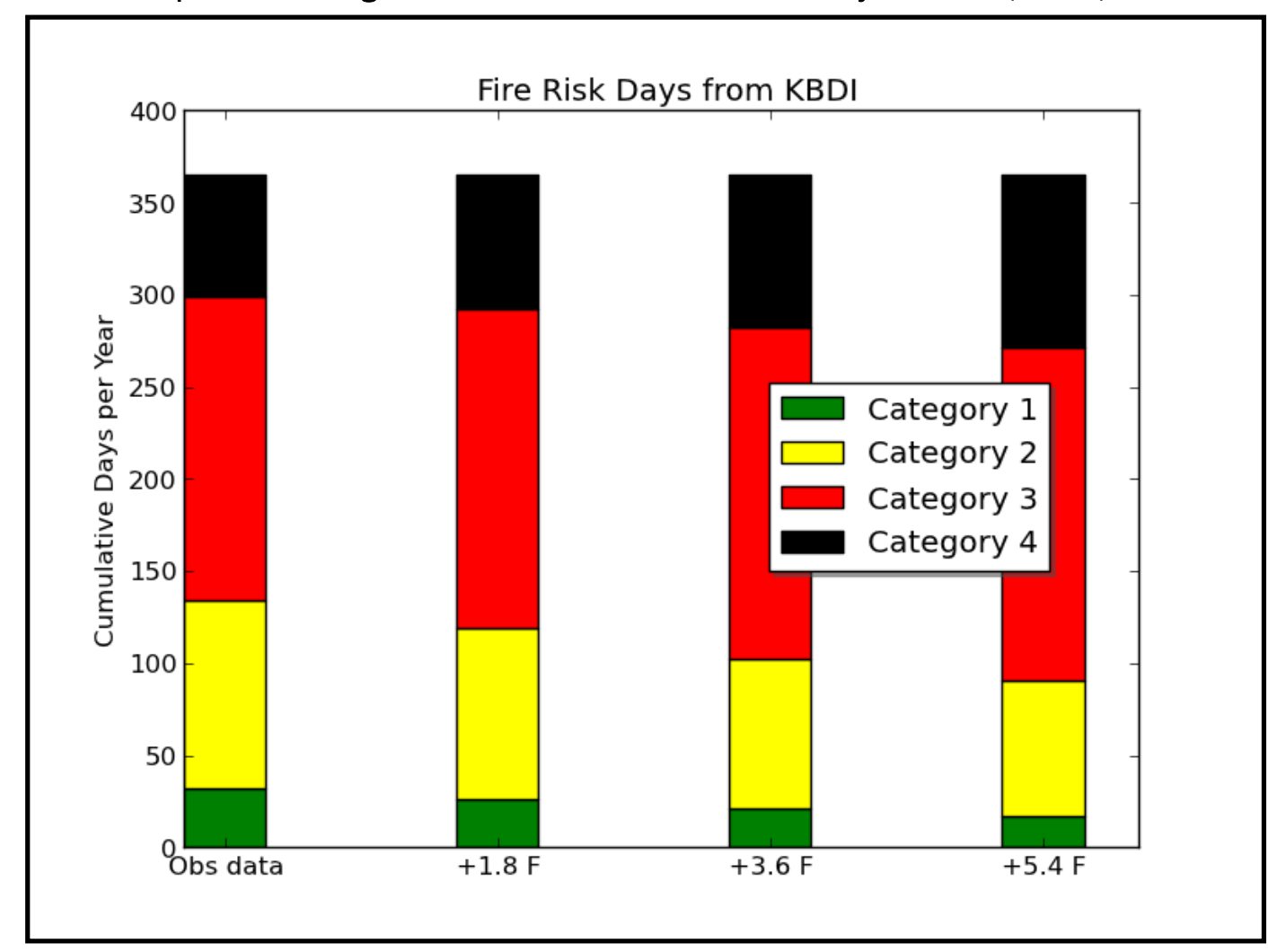

Table 4-4 lists the number of days in each fire risk category for the observed station data and for the projected temperature changes, for all seven sample installations. Of these installations, Fort Bliss has the lowest precipitation and the highest temperatures, so the largest overall fire risk. The KBDI at arid installations like Fort Bliss are sensitive to increases in precipitation, wetter installations like Fort Bragg are sensitive to decreases in precipitation. While the precipitation is kept unchanged in these calculations, all these installations have a wide range of precipitation change in the GCM projections under the A2 scenario (Figures 3-2 and 4-6 to 4-12). 
Table 4-4. Average number of days per year with calculated KBDI in the four categories from Tbl.4-1 for the example installations. The "Observed Data" column (uses the daily recorded temperatures and precipitation over 1979-1999, the projected columns (right three) used added temperature changes of $1.8,3.6$, and $5.4^{\circ} \mathrm{F}$.

\begin{tabular}{|c|c|c|c|c|c|}
\hline $\begin{array}{c}\text { Heat } \\
\text { Category }\end{array}$ & KBDI Range & Observed Data & $\begin{array}{c}\text { Observed } \\
+1.8^{\circ} \mathrm{F}\end{array}$ & $\begin{array}{l}\text { Observed } \\
+3.6^{\circ} \mathrm{F}\end{array}$ & $\begin{array}{l}\text { Observed } \\
+5.4^{\circ} \mathrm{F}\end{array}$ \\
\hline \multicolumn{6}{|c|}{ Fort Bliss } \\
\hline Cat 4 & $750-800$ & 82 & 87 & 94 & 101 \\
\hline Cat 3 & $600-750$ & 144 & 154 & 164 & 170 \\
\hline Cat 2 & $300-600$ & 103 & 97 & 87 & 79 \\
\hline Cat 1 & $0-300$ & 36 & 27 & 20 & 15 \\
\hline \multicolumn{6}{|c|}{ Fort Bragg } \\
\hline Cat 4 & $750-800$ & 0 & 0 & 0 & 0 \\
\hline Cat 3 & $600-750$ & 4 & 8 & 15 & 27 \\
\hline Cat 2 & $300-600$ & 114 & 137 & 164 & 179 \\
\hline Cat 1 & $0-300$ & 247 & 220 & 186 & 159 \\
\hline \multicolumn{6}{|c|}{ Fort Drum } \\
\hline Cat 4 & $750-800$ & 0 & 0 & 0 & 0 \\
\hline Cat 3 & $600-750$ & 0 & 0 & 0 & 0 \\
\hline Cat 2 & $300-600$ & 30 & 42 & 55 & 73 \\
\hline Cat 1 & $0-300$ & 335 & 323 & 310 & 292 \\
\hline \multicolumn{6}{|c|}{ JB Lewis-McChord } \\
\hline Cat 4 & $750-800$ & 0 & 0 & 0 & 0 \\
\hline Cat 3 & $600-750$ & 1 & 3 & 10 & 24 \\
\hline Cat 2 & $300-600$ & 87 & 97 & 105 & 104 \\
\hline Cat 1 & $0-300$ & 277 & 265 & 250 & 237 \\
\hline \multicolumn{6}{|c|}{ Fort Riley } \\
\hline Cat 4 & $750-800$ & 0 & 0 & 0 & 0 \\
\hline Cat 3 & $600-750$ & 8 & 12 & 25 & 38 \\
\hline Cat 2 & $300-600$ & 108 & 132 & 137 & 142 \\
\hline Cat 1 & $0-300$ & 249 & 221 & 203 & 185 \\
\hline \multicolumn{6}{|c|}{ Fort Wainwright } \\
\hline Cat 4 & $750-800$ & 0 & 0 & 0 & 0 \\
\hline Cat 3 & $600-750$ & 0 & 28 & 72 & 151 \\
\hline Cat 2 & $300-600$ & 180 & 167 & 189 & 130 \\
\hline Cat 1 & $0-300$ & 185 & 170 & 104 & 84 \\
\hline \multicolumn{6}{|c|}{ Schoefield, Wheeler AAF } \\
\hline Cat 4 & $750-800$ & 44 & 48 & 59 & 75 \\
\hline Cat 3 & $600-750$ & 79 & 92 & 102 & 114 \\
\hline Cat 2 & $300-600$ & 134 & 133 & 130 & 116 \\
\hline Cat 1 & $0-300$ & 108 & 92 & 74 & 60 \\
\hline
\end{tabular}


Figure 4-6. Climate projection plots for Fort Bliss, TX: (a) projected change in air temperature $\left({ }^{\circ} \mathrm{C}\right)$ versus precipitation (\%) for each of $36 \mathrm{GCMs}$ for the A2 scenario, between 1980-1999 and 2040-2060 (black points) and 2080-2090 (blue points); (b) average number of days per year with calculated WBGT in the five heat categories (with increasing temperatures of 1,2 , and $3{ }^{\circ} \mathrm{C}\left(3.6,1.8\right.$, and $\left.5.4^{\circ} \mathrm{F}\right)$; (c) average number of days per year with calculated KBDI categories with increasing temperatures of 1,2 , and $3^{\circ} \mathrm{C}\left(3.6,1.8\right.$, and $\left.5.4{ }^{\circ} \mathrm{F}\right)$.

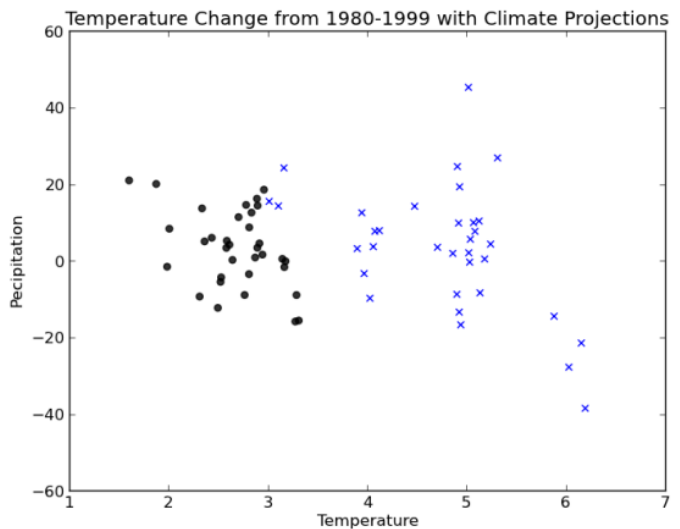

a.

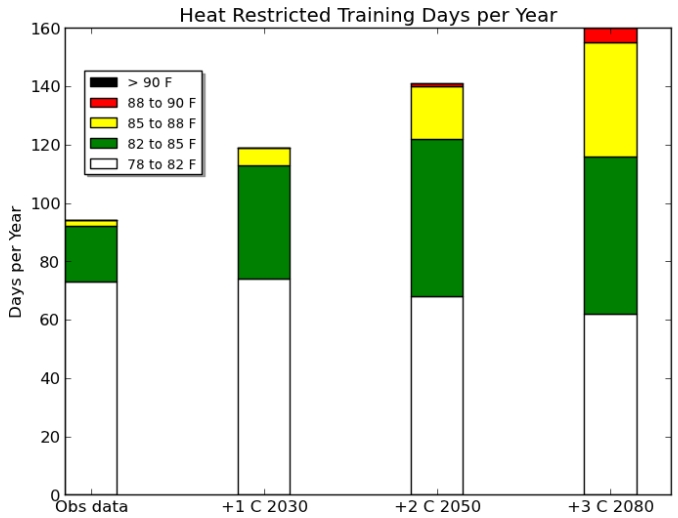

b.

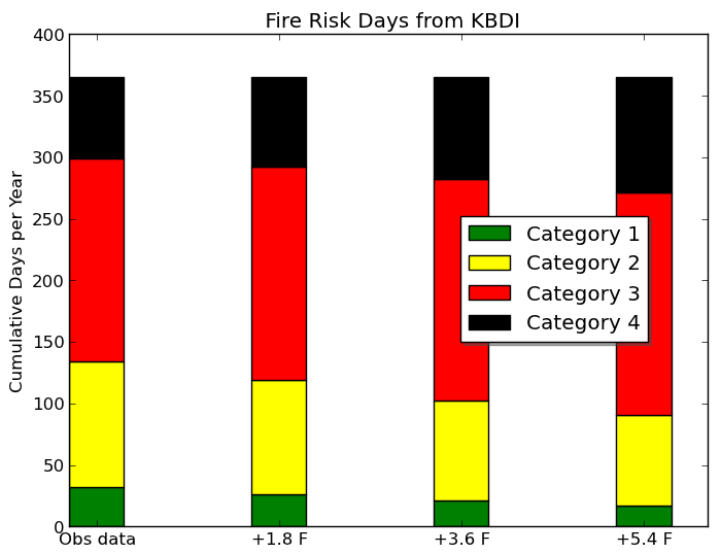

c. 
Figure 4-7. Climate projection plots for Fort Bragg, NC: (a) projected change in air temperature $\left({ }^{\circ} \mathrm{C}\right)$ versus precipitation (\%) for each of $36 \mathrm{GCMs}$ for the A2 scenario, between 1980-1999 and 2040-2060 (black points) and 2080-2090 (blue points); (b) average number of days per year with calculated WBGT in the five heat categories (with increasing temperatures of 1,2 , and $3{ }^{\circ} \mathrm{C}$ $\left(3.6,1.8\right.$, and $\left.5.4^{\circ} \mathrm{F}\right)$; (c) average number of days per year with calculated KBDI categories with increasing temperatures of 1,2 , and $3^{\circ} \mathrm{C}\left(3.6,1.8\right.$, and $\left.5.4^{\circ} \mathrm{F}\right)$.

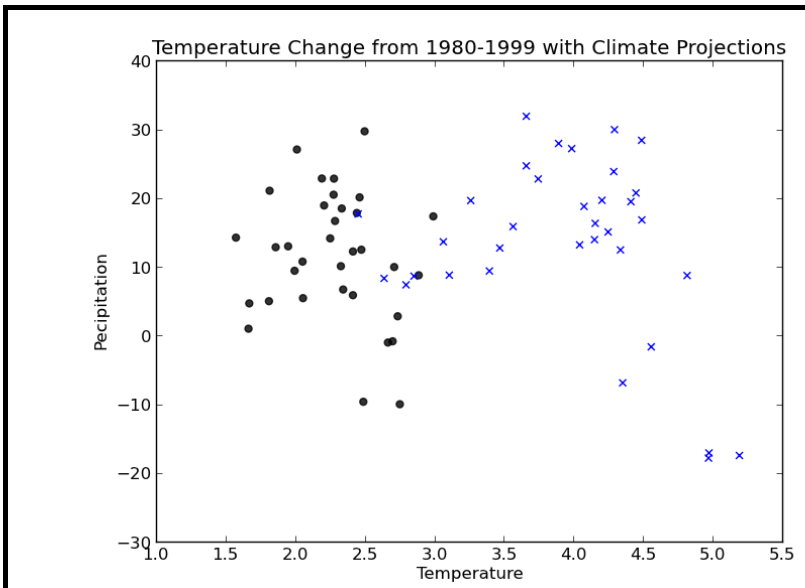

a.

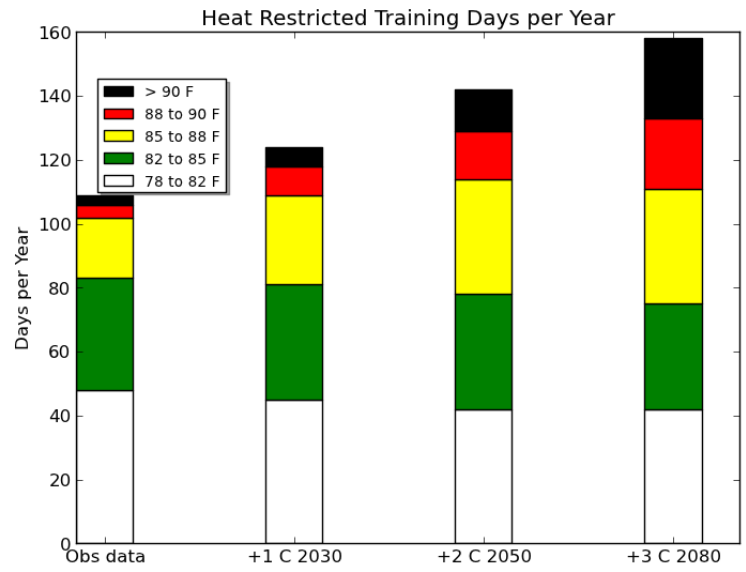

b.

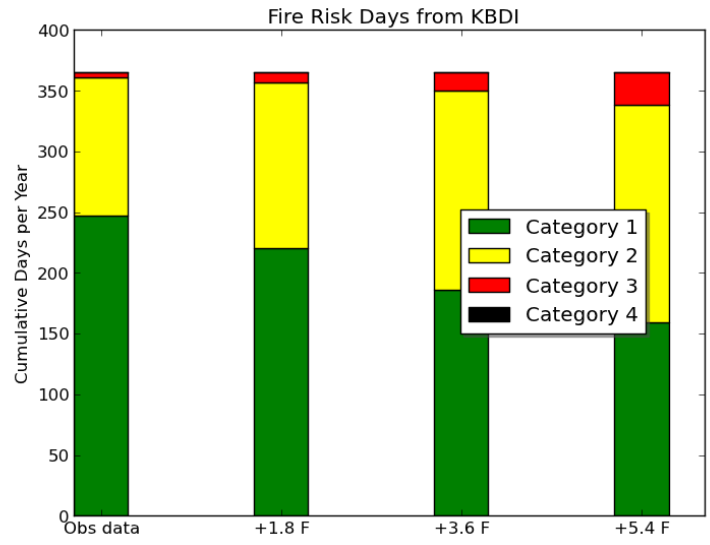

C. 
Figure 4-8. Climate projection plots for Fort Drum, NY: (a) projected change in air temperature $\left({ }^{\circ} \mathrm{C}\right)$ versus precipitation (\%) for each of $36 \mathrm{GCMs}$ for the A2 scenario, between 1980-1999 and 2040-2060 (black points) and 2080-2090 (blue points); (b) average number of days per year with calculated WBGT in the five heat categories (with increasing temperatures of 1,2 , and $3{ }^{\circ} \mathrm{C}$ $\left(3.6,1.8\right.$, and $\left.5.4^{\circ} \mathrm{F}\right)$; (c) average number of days per year with calculated KBDI categories with increasing temperatures of 1,2 , and $3^{\circ} \mathrm{C}\left(3.6,1.8\right.$, and $\left.5.4^{\circ} \mathrm{F}\right)$.

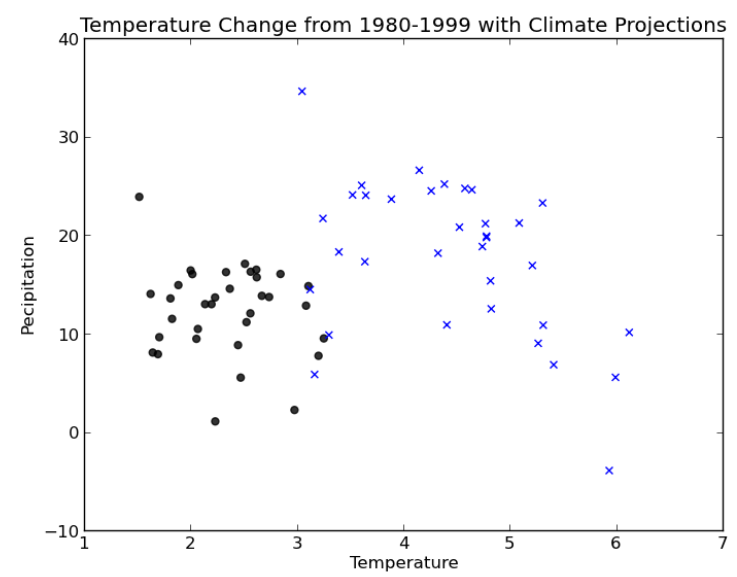

a.

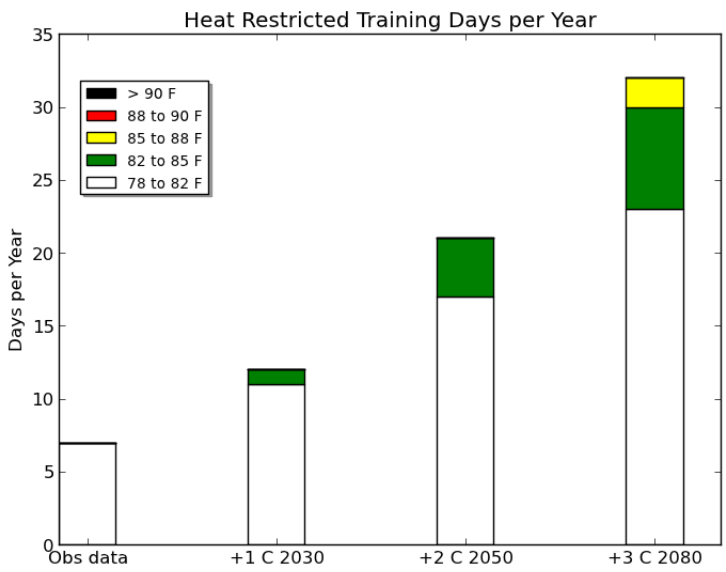

b.

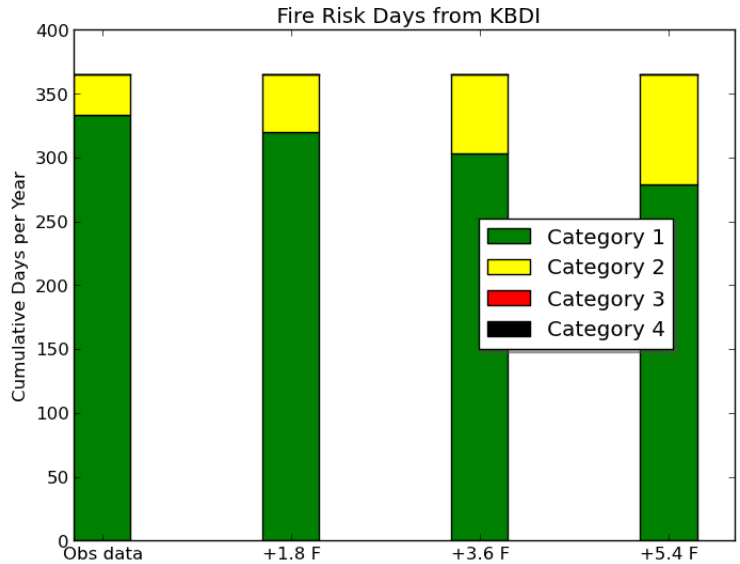

c. 
Figure 4-9. Climate projection plots for Joint Base Lewis-McChord, WA: (a) projected change in air temperature $\left({ }^{\circ} \mathrm{C}\right.$ ) versus precipitation (\%) for each of $36 \mathrm{GCMs}$ for the A2 scenario, between 1980-1999 and 2040-2060 (black points) and 2080-2090 (blue points); (b) average number of days per year with calculated WBGT in the five heat categories (with increasing temperatures of 1,2 , and $3^{\circ} \mathrm{C}\left(3.6,1.8\right.$, and $\left.5.4{ }^{\circ} \mathrm{F}\right)$; (c) average number of days per year with calculated KBDI categories with increasing temperatures of 1,2 , and $3{ }^{\circ} \mathrm{C}(3.6$, 1.8 , and $\left.5.4^{\circ} \mathrm{F}\right)$.

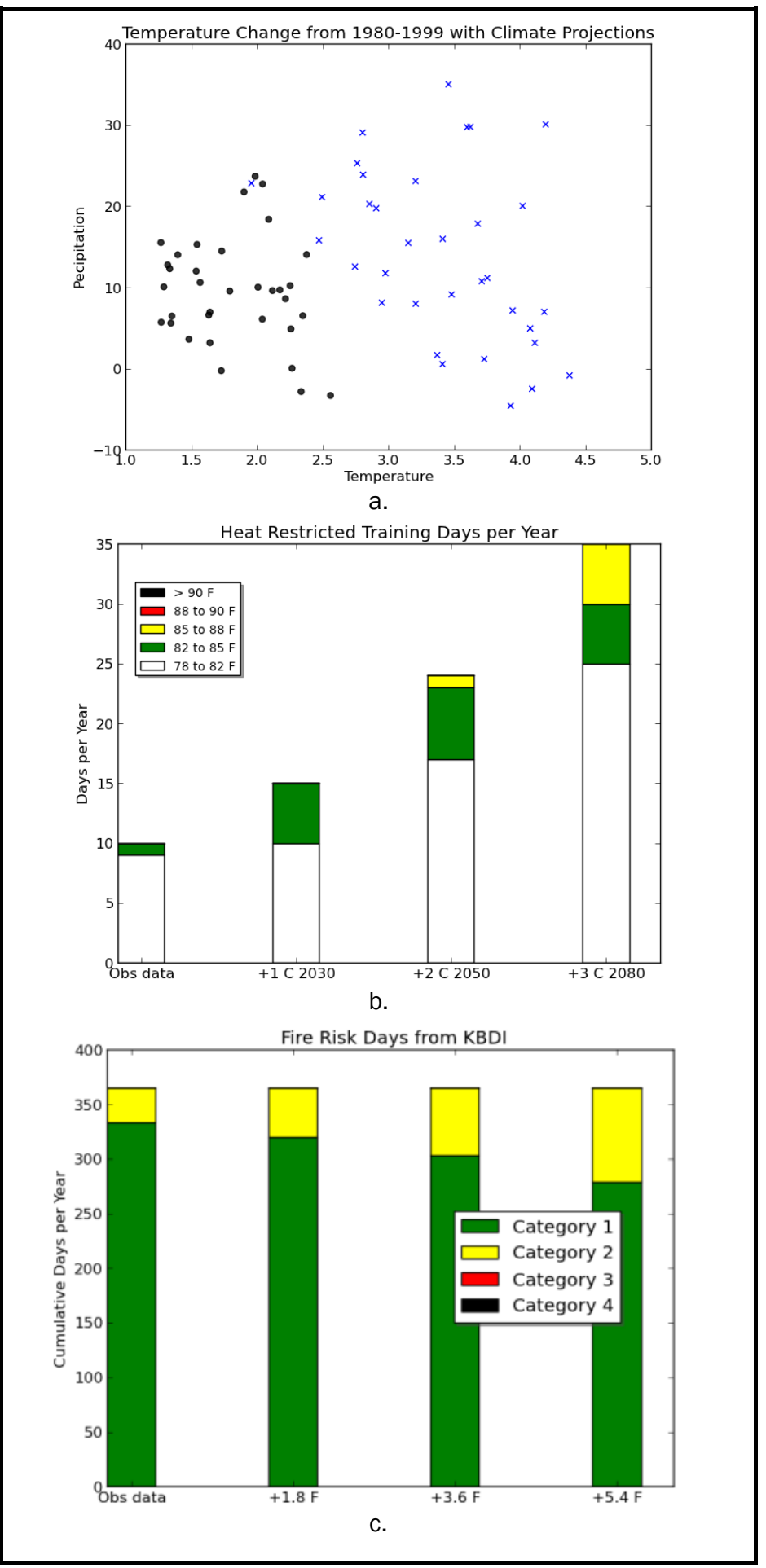


Figure 4-10. Climate projection plots for Fort Riley, KS: (a) projected change in air temperature $\left({ }^{\circ} \mathrm{C}\right)$ versus precipitation (\%) for each of $36 \mathrm{GCMs}$ for the A2 scenario, between 1980-1999 and 2040-2060 (black points) and 2080-2090 (blue points); (b) average number of days per year with calculated WBGT in the five heat categories (with increasing temperatures of 1,2 , and $3{ }^{\circ} \mathrm{C}$ $\left(3.6,1.8\right.$, and $\left.5.4^{\circ} \mathrm{F}\right)$; (c) average number of days per year with calculated KBDI categories with increasing temperatures of 1,2 , and $3^{\circ} \mathrm{C}\left(3.6,1.8\right.$, and $\left.5.4^{\circ} \mathrm{F}\right)$.

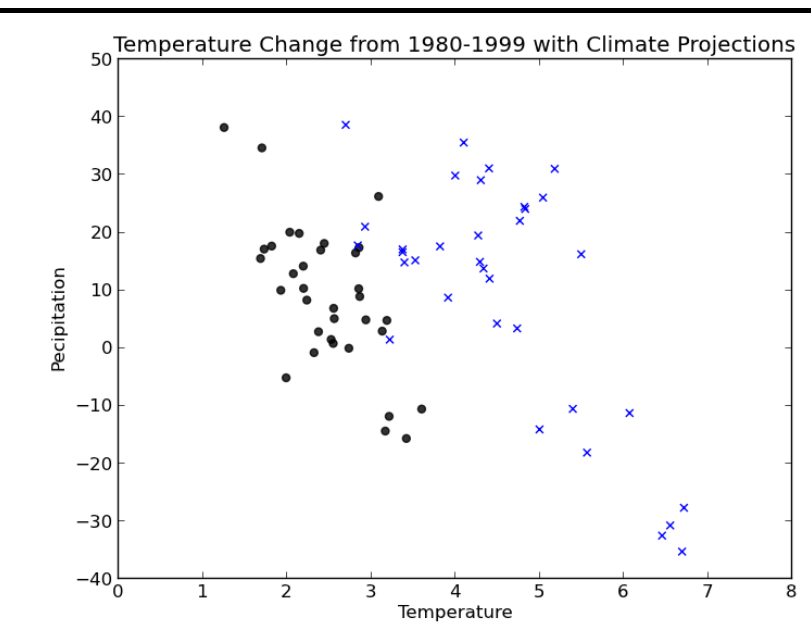

a.

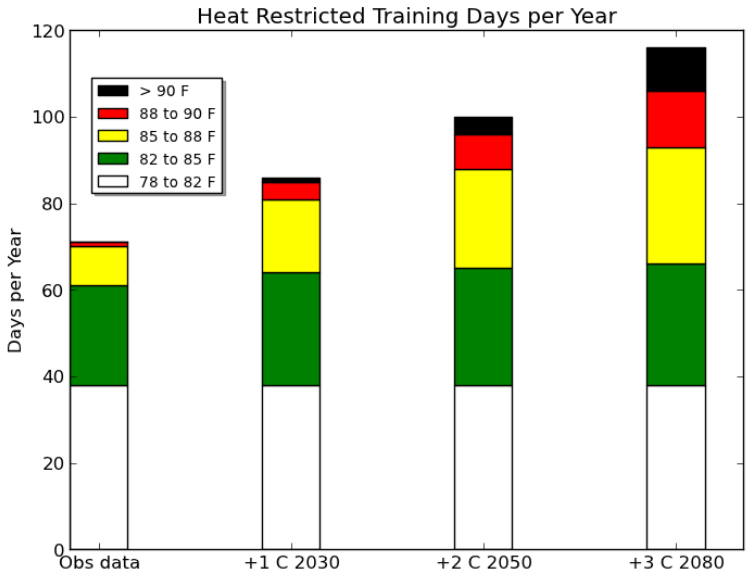

b.

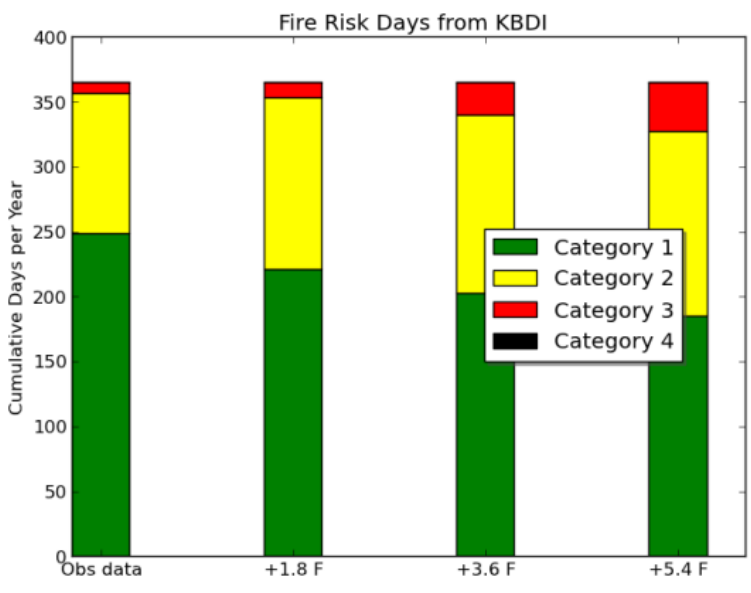

C. 
Figure 4-11. Climate projection plots for Fort Wainwright, AK: (a) projected change in air temperature $\left({ }^{\circ} \mathrm{C}\right.$ ) versus precipitation (\%) for each of $36 \mathrm{GCMs}$ for the A2 scenario, between 1980-1999 and 2040-2060 (black points) and 2080-2090 (blue points); (b) average number of days per year with calculated WBGT in the five heat categories (with increasing temperatures of 1,2 , and $3{ }^{\circ} \mathrm{C}\left(3.6,1.8\right.$, and $\left.5.4^{\circ} \mathrm{F}\right)$; (c) average number of days per year with calculated KBDI categories with increasing temperatures of 1,2 , and $3{ }^{\circ} \mathrm{C}\left(3.6,1.8\right.$, and $\left.5.4{ }^{\circ} \mathrm{F}\right)$.

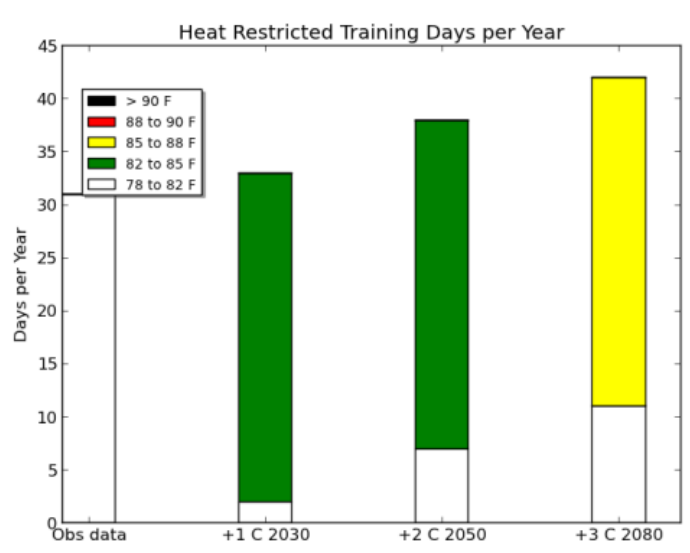

a.

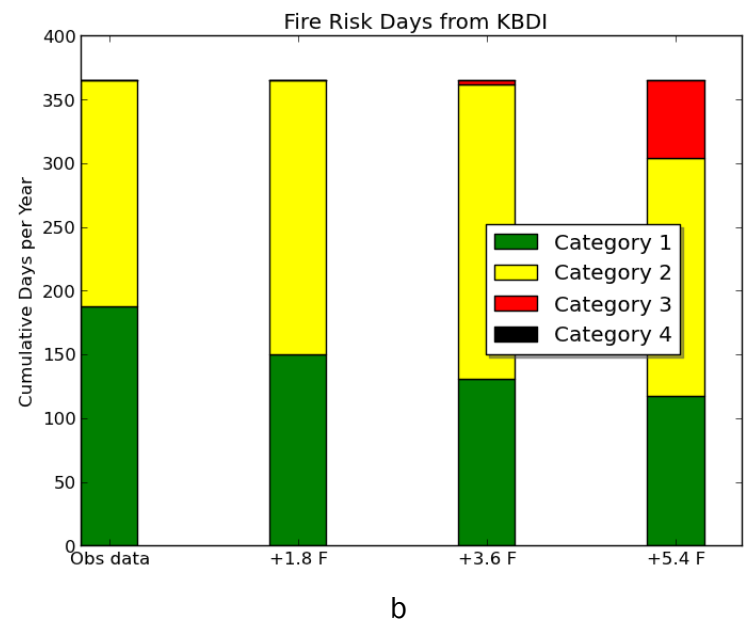


Figure 4-12. Climate projection plots for Wheeler AAF - Schoefield Barracks HI: (a) projected change in air temperature $\left({ }^{\circ} \mathrm{C}\right.$ ) versus precipitation (\%) for each of $36 \mathrm{GCMs}$ for the A2 scenario, between 1980-1999 and 2040-2060 (black points) and 2080-2090 (blue points); (b) average number of days per year with calculated WBGT in the five heat categories (with increasing temperatures of 1,2 , and $3{ }^{\circ} \mathrm{C}\left(3.6,1.8\right.$, and $\left.5.4^{\circ} \mathrm{F}\right) ;$ (c) average number of days per year with calculated KBDI categories with increasing temperatures of 1,2 , and $3{ }^{\circ} \mathrm{C}(3.6$, 1.8 , and $5.4^{\circ} \mathrm{F}$ ).

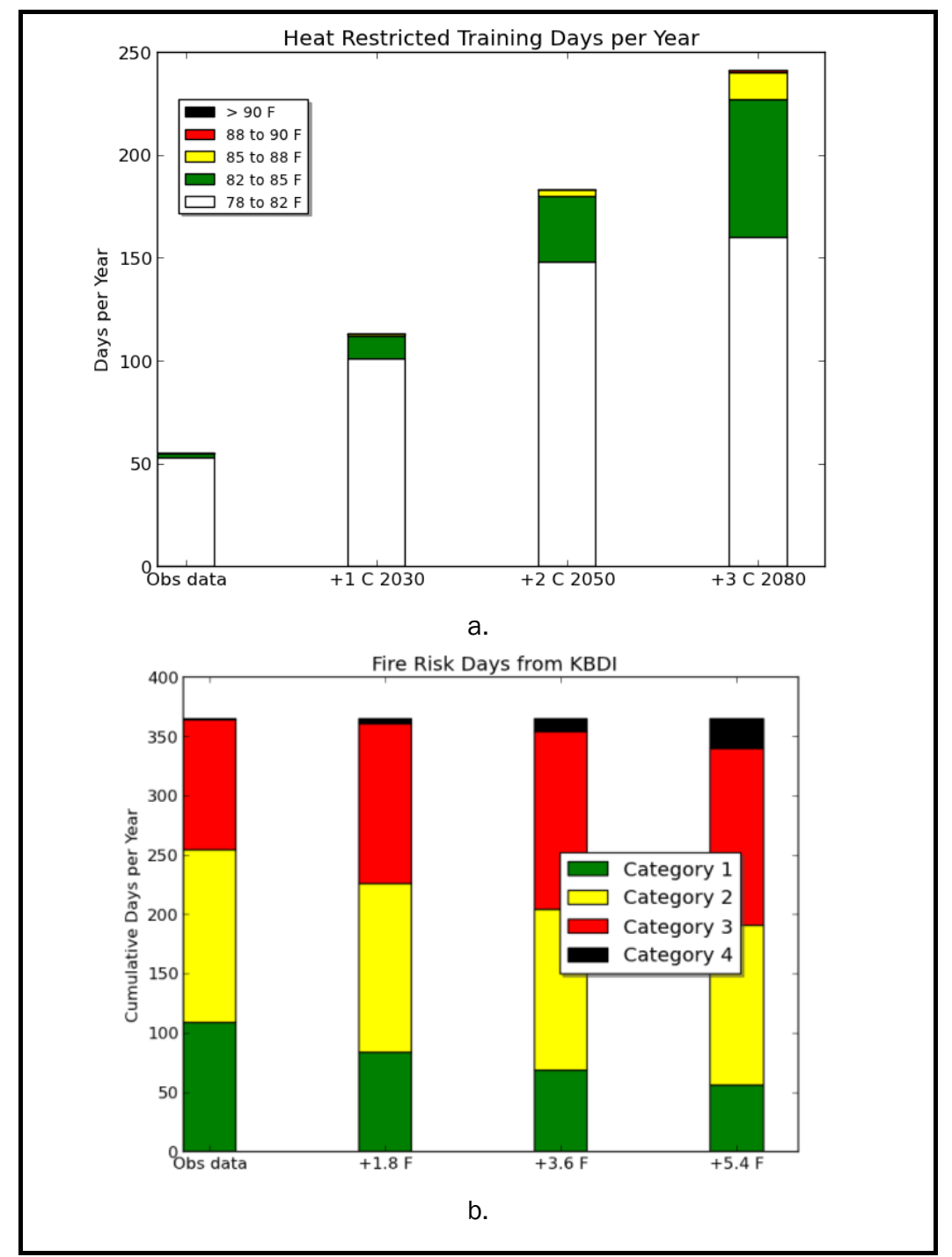

\subsection{Combined results for all installations}

Figures 4-6 to 4-12 show the three different plots of results for each installation in this sample. The upper plots of Figures 4-6 to 4-12 show the range of temperature and precipitation changes for the installations across the GCMs for the A2 scenario. The projections of precipitation (on the vertical axis) are more variable and uncertain than those of temperature (horizontal axis), as the precipitation spans the range of $-40 \%$ to $+40 \%$ for the 2080 timeframe. While this range may result in a modest change in just 
the multimodel average, subsequent work will consider the risks to installations across the full range of GCM projections. It seems clear that a comprehensive analysis of risks for any installation should consider the potential impacts from a $\pm 40 \%$ change in precipitation and not simply the multimodel mean of $\pm 3 \%$ change. Fort Wainwright, AK and Wheeler Army Airfield, HI do not have the plot of GCM projections shown in Figures 4-6 to 4-12 since the original Maurer et al. (2007) version of downscaled BCSD projections were developed for CONUS locations only. However, other global GCM projections are now available for Outside Continental United States (OCONUS) locations.

Of these installations, the heat-related impacts to training are significant for Fort Bragg, Fort Riley, and Fort Bliss in that there are at least 30 days with heat restrictions in the Category 2 to 5 range. The days with these restrictions are all projected to increase with temperature by 30 days or more, with the greatest change at Fort Bragg, where humidity also contributes to the computed heat stress. Northern locations (Fort Drum, JB Lewis-McChord, Fort Wainwright) have significantly less overall risk of increasing heat impacts.

The fire risks to training at the installations is greatest at the southwestern U.S. locations (Fort Bliss and Fort Riley), which is consistent with their low precipitation and high temperatures. The fire risks are projected to increase the most at these two locations, and also to significantly increase at JB Lewis-McChord. These impacts depend highly on the projected precipitation change that varies greatly across GCMs and regionally across the United States. Future work will consider the full range of these GCM projections in the risks for all the installations in this study. 


\section{Conclusions and Recommendations}

\subsection{Conclusions}

Projected impacts of climate change on Army installation are expected to affect multiple aspects of the Army mission, including training, operations and maintenance of installations and infrastructure, environmental sustainability, and resource conservation. This FY14 study considered the projected impacts of climate on two climate-related indices that are indicators of restrictions on training: a heat index (WBGT) and a fire risk/drought index (KBDI). The heat index WBGT includes the effects of air temperature, humidity, wind, and solar radiation. The fire risk index includes the effects of temperature and precipitation. These indices were computed using observed daily weather station data for seven sample Army installations in the United States: (1) Fort Bliss, TX, (2) Fort Bragg, NC, (3) Fort Drum, NY, (4) Fort Riley, KS, (5) JB Lewis-McChord, WA, (6) Fort Wainwright, AK, and (7) Shoefield Barracks-Wheeler AAF, HI.

Future climate change projections used a set of statistically-downscaled climate projections from GCMs. Precipitation changes vary widely across these models, while temperatures generally increase with time through 2090s. Based on these projections, a set of future projections of heat-risk days and fire risk days was developed based on increasing temperatures only for the seven sample installations.

This work concludes that the impacts of increasing temperatures in the sample installations was greatest in the southeast United States (Fort Bragg) due the higher humidity in the southeast. Fort Bragg showed an increase of over 40 days in all levels of heat restriction for a projected increase in $5.4{ }^{\circ} \mathrm{F}\left(3^{\circ} \mathrm{C}\right)$ in daily temperatures, primarily increasing in the highest heat category of WBGT $>85^{\circ} \mathrm{F}\left(>29.4{ }^{\circ} \mathrm{C}\right)$. All the U.S. sample installations are projected to experience increases in heat restriction days, though most northern U.S. locations would still not significantly be affected by high-heat impacts on an annual basis through 2090.

As expected, this work concludes that the fire risk impact was greatest in the southwest United States (Fort Bliss TX) due to the low precipitation and high temperatures. In general, fire risk increases with increasing temperature; all the installations have increases in KBDI with increased temperatures. However, the central and southwest United States is projected 
to get less precipitation, particularly in the summer season, that will also exacerbate the fire risk at these locations. The northern U.S. locations are likely to experience increases in precipitation that should reduce fire risks in general, in spite of increasing temperatures.

\subsection{Recommendations}

Results of this work were developed as a first-year demonstration of the climate impacts that are being developed in this larger project. To develop a more comprehensive set of climate-related impacts for Army installations that relate to impacts on the training mission, it is recommended that this project development be expanded to include:

- All CONUS-wide data, which will include all locations of CONUS Army installations (including other U.S. Department of Defense [DoD], National Guard and reserve locations)

- Developing the climate indices for extreme precipitation, wind, and storm events

- The full range of available GCM projections and future climate scenarios from the IPCC.

In general, development should expand the observed data analysis from pointwise weather station data to use of the CONUS-wide data such as North American Regional Reanalysis (NARR) data. This will allow for the analysis of the CONUS-wide thresholds of the top $99^{\text {th }}$ percentile of temperature and precipitation events and include the impact of climate projections on these levels.

The expansion of the impacts for the installations will also include the computation of heat-stress days for both day (maximum) and night (minimum) training conditions, based on the Army Medical training restrictions for work/rest limits. Since much of the Army training occurs at times other than the maximum daily temperatures and sunlight, these times must be taken into consideration.

It is recommended that the analysis be expanded to consider the full range of climate projections across the GCMs and all available emissions scenarios from the IPCC, including the RCP 4.5, 6.0 and 8.5. Since it is not possible to reliably predict that any one scenario is more likely to occur than another, it is prudent to include the widest range of possible impacts to Army installations and the Army mission. 


\section{Acronyms and Abbreviations}

\begin{tabular}{|c|c|}
\hline Term & Definition \\
\hline AAF & Army Airfield \\
\hline AFB & Air Force Base \\
\hline BCSD & Bias-Corrected Statistical Downscaling \\
\hline CDD & Total Cooling Degree Days \\
\hline CEERD & U.S. Army Corps of Engineers, Engineer Research and Development Center \\
\hline CFC & Chlorofluorocarbon \\
\hline CMIP & Coupled Model Intercomparison Project \\
\hline CONUS & Continental United States \\
\hline CRREL & Cold Regions Research and Engineering Laboratory \\
\hline CSIRO & Australia's Commonwealth Scientific and Industrial Research Organization \\
\hline DoD & U.S. Department of Defense \\
\hline ERDC & Engineer Research and Development Center \\
\hline ERDC-CRREL & $\begin{array}{l}\text { Engineer Research and Development Center, Cold Regions Research and } \\
\text { Engineering Laboratory }\end{array}$ \\
\hline GCM & Global Climate Model \\
\hline GHG & Greenhouse Gas \\
\hline HDD & Heating Degree Day \\
\hline IPCC & Intergovernmental Panel on Climate Change \\
\hline$J B$ & Joint Base \\
\hline KBDI & Keetch-Byram Drought Index \\
\hline LCM & Local Climate Model \\
\hline NARCCAP & North American Regional Climate Change Assessment Project \\
\hline NARR & North American Regional Reanalysis \\
\hline NASA & National Aeronautics and Space Administration \\
\hline NCAR & National Centre for Atmospheric Research \\
\hline NOAA & National Oceanic and Atmospheric Administration \\
\hline OCONUS & Outside Continental United States \\
\hline $\mathrm{RCM}$ & Regional Climate Model \\
\hline $\mathrm{RCP}$ & Representative Concentration Path \\
\hline SERDP & Strategic Environmental Research and Development Program \\
\hline TB & Technical Bulletin \\
\hline TR & Technical Report \\
\hline UK & United Kingdom \\
\hline WBGT & Wet Bulb-Black Globe Temperature \\
\hline WCRP & World Climate Research Programme \\
\hline
\end{tabular}




\section{References}

Alexander, M. E. 1990. Computer Calculation of the Keetch-Byram Drought IndexProgrammers Beware! Fire Management Notes 51(4):23-25. Washington, DC: U.S. Department of Agriculture (USDA) Forest Service, http://www.fs.fed.us/fire/fmt/fmt_pdfs/051_04.pdf

Brown, C. S., S. Steinschneider, J. W. Wi, M. Weatherly, T. Case, L. Hayden, M. Mearns, R. Bukovsky, and R. McCrary. 2013. Decision-Scaling: A decision framework for DoD climate risk assessment and adaptation planning. Strategic Environmental Research and Development Program (SERDP) project RC-2204, Interim report.

Bureau of Reclamation. 2014. Downscaled CMIP3 and CMIP5 Climate and Hydrology Projections. Web page. http://gdo-dcp.ucllnl.org/downscaled_cmip_projections/dcpInterface.html\#About

Christensen, J. H., B. Hewitson, A. Busuioc, A. Chen, X. Gao, I. Held, R. Jones, R. K. Kolli, W.-T. Kwon, R. Laprise, V. Magaña Rueda, L. Mearns, C.G. Menéndez, J. Räisänen, A. Rinke, A. Sarr, and P. Whetton. 2007. Regional Climate Projections. Climate Change 2007: The Physical Science Basis. Contribution of Working Group I to the Fourth Assessment Report of the Intergovernmental Panel on Climate Change. Cambridge, United Kingdom and New York, NY: Cambridge University Press.

Crane. W. J. B. 1982. Computing grassland and forest fire behaviour relative humidity and drought index by pocket calculator. Australian Forestry. 45(:1):89-97.

Headquarters, Department of the Army (HQDA). 2003. Heat Stress Control and Heat Casualty Management. Army Technical Bulletin Medical 507 (TB MED 507). Washington DC: HQDA, http://armypubs.army.mil/med/dr_pubs/dr_a/pdf/tbmed507.pdf

Intergovernmental Panel on Climate Change (IPCC). 2007. Climate change 2007-The physical science basis. Contribution of Working Group I to the Fourth Assessment Report of the Intergovernmental Panel on Climate Change. Cambridge, United Kingdom: Cambridge University Press, http://www.ipcc.ch/ipccreports/ar4-wg1.htm

Keetch. J. J., G. M. Byram. 1968 (rev. 1988). A drought index for forest fire control. Research Paper SE-38. Asheville NC: USDA Forest Service, Southeastern Forest Experiment Station.

Maurer, E. P., L. Brekke, T. Pruitt, and P. B. Duffy. 2007. Fine-resolution climate projections enhance regional climate change impact studies. Eos, Transactions of the American Geophysical Union 88(47):504.

Mearns, L. O., W. J. Gutowski, R. Jones, L.-Y. Leung, S. McGinnis, A. M. B. Nunes, and Y. Qian. 2009. A regional climate change assessment program for North America. Eos, Transactions of the American Geophysical Union 90(36):311-312. 
Meehl, G. A., C. Covey, T. Delworth, M. Latif, B. McAvaney, J. F. B. Mitchell, R. J. Stouffer, and K. E. Taylor. 2007. The WCRP CMIP3 multi-model dataset: A new era in climate change research. Bulletin of the American Meteorological Society 88(9):1383-1394.

Melillo, J. M., T. C. Richmond, G W. Yohe, eds. 2014. Climate Change Impacts in the United States: The Third National Climate Assessment. U.S. Global Change Research Program. doi 10.7930/JOZ31WJ2.

Nakicenovic, N., J. Alcamo, G. Davis, B. de Vries, J. Fenhann, S. Gaffin, K. Gregory, A. Grübler, T. Y. Jung, T. Kram, E. L. La Rovere, L. Michaelis, S. Mori, T. Morita, W. Pepper, H. Pitcher, L. Price, K. Riahi, A. Roehrl, H. Rogner, A. Sankovski, M. Schlesinger, P. Shukla, S. Smith, R. Swart, S. van Rooijen, N. Victor, and Z. Dadi. 2000. Special Report on Emissions Scenarios: A Special Report of Working Group III of the Intergovernmental Panel on Climate Change. Cambridge University Press, Cambridge, UK, http://www.grida.no/climate/ipcc/emission/index.htm

Walsh, J. E., W. L. Chapman, V. Romanovsky, J. H. Christensen, and M. Stendel. 2008. Global climate model performance over Alaska and Greenland. J. Climate 21:6156-6174. doi 10.1175/2008jcli2163.1. 


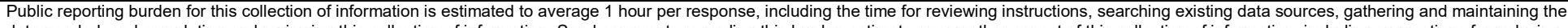

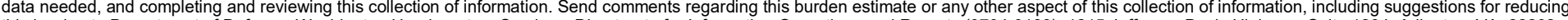

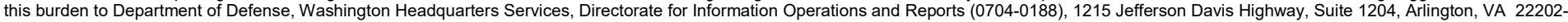

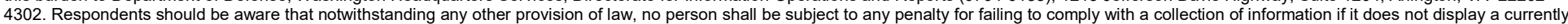
valid OMB control number. PLEASE DO NOT RETURN YOUR FORM TO THE ABOVE ADDRESS.

\begin{tabular}{l|l} 
valid OMB control number. PLEASE DO NOT RETURN YOUR FORM TO THE ABOVE ADDRESS. \\
\hline 1. REPORT DATE (DD-MM-YYYY) & 2. REPOR
\end{tabular}

\begin{tabular}{|c|c|c|}
$11 / 27 / 2017$ & Final \\
\hline
\end{tabular}

\section{TITLE AND SUBTITLE}

Use of Heat and Fire-Risk Indices to Project Local Climate Impacts on Selected Army Installations:

Climate Models, Scenarios, Climate Data, and Indices

3. DATES COVERED (From - To)

5a. CONTRACT NUMBER

\section{5b. GRANT NUMBER}

\section{5c. PROGRAM ELEMENT}

\section{AUTHOR(S)}

John W. Weatherly and Mattson A. Rosenbaum

\section{5d. PROJECT NUMBER}

$622720 A 896$

5e. TASK NUMBER

\section{5f. WORK UNIT NUMBER}

$\mathrm{L}_{4} \mathrm{~F}_{5} \mathrm{G} 1$

7. PERFORMING ORGANIZATION NAME(S) AND ADDRESS(ES)

U.S. Army Engineer Research and Development Center (ERDC)

8. PERFORMING ORGANIZATION REPORT Cold Regions Research and Engineering Laboratory (CRREL)

72 Lyme Road, NUMBER

Hanover, NH $03755^{-1290}$

ERDC/CRREL TR-17-17

\section{SPONSORING / MONITORING AGENCY NAME(S) AND ADDRESS(ES)}

Headquarters, U.S. Army Corps of Engineers (HQUSACE)

441 G St., NW

Washington, DC 20314-1000

10. SPONSOR/MONITOR'S ACRONYM(S) HQDA

11. SPONSOR/MONITOR'S REPORT NUMBER(S)

\section{DISTRIBUTION / AVAILABILITY STATEMENT}

Approved for public release; distribution is unlimited.

\section{SUPPLEMENTARY NOTES}

\section{ABSTRACT}

Climate change is expected to produce increasing impacts on training and infrastructure on Army installations in the coming decades. Planning to enable Army installations to adapt to the changing climate can be supported by suitable estimates of climate impacts over timeframes suitable for strategic plans. This work computed the impacts of future climate change on available training days for seven sample Army installations using projections of temperature and precipitation from global climate models. The number of days with heat-related training restrictions and fire risk from live-fire training were calculated using observed weather station data and climate model projections for several future climate scenarios. For these installations, increased temperatures in time periods centered on 2030 , 2050 , and 2090 result in a greater number of days with heat categories above 84 and $90{ }^{\circ} \mathrm{F}\left(28.9\right.$ and $\left.32.2^{\circ} \mathrm{C}\right)$ and with high fire risk. The climate impact on heat-affected training days is greater in the U.S. Southeast, where high humidity also contributes most to the heat index. The impact on the fire risk for training is greater in the U.S. Southwest, where the low precipitation and high temperatures contribute to the high drought index. Future work will include additional installations and climate variables.

\section{SUBJECT TERMS}

Climatic changes--Risk assessment, Climatic changes--Forecasting, Military bases, Fire risk assessment, Heat exhaustion

\begin{tabular}{|c|c|c|}
\hline \multicolumn{3}{|c|}{ 16. SECURITY CLASSIFICATION OF: } \\
\hline $\begin{array}{l}\text { a. REPORT } \\
\text { Unclassified }\end{array}$ & $\begin{array}{l}\text { b. ABSTRACT } \\
\text { Unclassified }\end{array}$ & $\begin{array}{l}\text { c. THIS PAGE } \\
\text { Unclassified }\end{array}$ \\
\hline
\end{tabular}

\begin{tabular}{|c|c|c|}
\hline $\begin{array}{c}\text { 17. LIMITATION } \\
\text { OF ABSTRACT }\end{array}$ & $\begin{array}{c}\text { 18. NUMBER } \\
\text { OF PAGES }\end{array}$ & \begin{tabular}{c} 
19a. NAME OF RESPONSIBLE PERSON \\
\cline { 3 - 3 } SAR
\end{tabular} \\
\cline { 3 - 3 } & 48 & $\begin{array}{c}\text { 19b. TELEPHONE NUMBER } \\
\text { (include area code) }\end{array}$ \\
\hline
\end{tabular}

